\title{
Introduction of a Methyl Group Curbs Metabolism of Pyrido[3,4-d]pyrimidine Monopolar Spindle 1 (MPS1) Inhibitors and Enables the Discovery of the Phase 1 Clinical Candidate $N^{2}-(2-$ Ethoxy-4-(4-methyl-4H-1,2,4-triazol-3-yl)phenyl)-6- methyl- $N^{8}$-neopentylpyrido[3,4-d]pyrimidine-2,8-diamine (BOS172722)
}

Hannah L. Woodward, ${ }^{\dagger}$ Paolo Innocenti, ${ }^{\dagger}$ Kwai-Ming J. Cheung, ${ }^{\dagger}$ Angela Hayes, ${ }^{\dagger}$ Jennie Roberts, ${ }^{\dagger}$ Alan T. Henley, ${ }^{\dagger}$ Amir Faisal, ${ }^{\dagger, \perp}$ Grace Wing-Yan Mak, ${ }^{\dagger}$ Gary Box, ${ }^{\dagger}$ Isaac M. Westwood, ${ }^{\dagger,}$ Nora Cronin, ${ }^{\ddagger}$ Michael Carter, ${ }^{\dagger}$ Melanie Valenti, ${ }^{\dagger}$ Alexis De Haven Brandon, ${ }^{\dagger}$ Lisa O’Fee, ${ }^{\dagger}$ Harry Saville, ${ }^{\dagger}$ Jessica Schmitt, ${ }^{\dagger}$ Rosemary Burke, ${ }^{\dagger}$ Fabio Broccatelli, ${ }^{\dagger}$ Rob L. M. van Montfort, ${ }^{\dagger, \dagger}$ Florence I. Raynaud, ${ }^{\dagger}$ Suzanne A. Eccles, ${ }^{\dagger}$ Spiros Linardopoulos, ${ }^{\dagger, \S}$ Julian Blagg, $^{\dagger}$ and Swen Hoelder* ${ }^{\dagger}{ }^{\dagger}$

${ }^{\dagger}$ Cancer Research UK Cancer Therapeutics Unit at The Institute of Cancer Research, London SM2 5NG, United Kingdom

${ }^{\ddagger}$ Division of Structural Biology, The Institute of Cancer Research, London SW3 6JB, United Kingdom

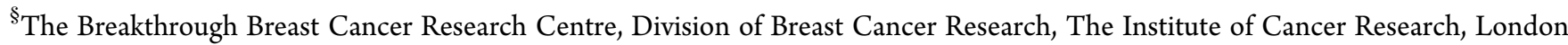
SW3 6JB, United Kingdom

\section{Supporting Information}

ABSTRACT: Monopolar spindle 1 (MPS1) occupies a central role in mitosis and is one of the main components of the spindle assembly checkpoint. The MPS1 kinase is an attractive cancer target, and herein, we report the discovery of the clinical candidate BOS172722. The starting point for our work was a series of pyrido $[3,4-d]$ pyrimidine inhibitors that demonstrated excellent potency and kinase selectivity but suffered from rapid turnover in human liver microsomes (HLM). Optimizing HLM stability proved challenging since it was not possible to identify a consistent site of metabolism and lowering lipophilicity proved unsuccessful. Key to overcoming this problem was the finding that introduction of a methyl group at the 6-position of the pyrido $[3,4-d]$ pyrimidine core significantly improved HLM stability. Met ID studies suggested that the methyl group suppressed metabolism at the distant aniline portion of the molecule, likely by blocking the preferred pharmacophore through which P450 recognized the compound. This work ultimately led to the discovery of BOS172722 as a Phase 1 clinical candidate.

\section{INTRODUCTION}

MPS1 (monopolar spindle 1, also known as TTK) is a dualspecificity kinase that occupies a central role in mitosis. MPS1 is one of the main components of the spindle assembly checkpoint (SAC) ${ }^{1-4}$ and ensures cells do not progress from metaphase to anaphase until the kinetochores are properly attached to the microtubules and under the appropriate tension at the metaphase plate. ${ }^{2,3}$ Cancer cells heavily rely on MPS1 to cope with aneuploidy resulting from aberrant numbers of chromosomes. ${ }^{5-8}$ The kinase has been found to be upregulated in a large number of tumor types, $6,7,-13$ strongly suggesting MPS1 inhibition as a therapeutic approach for the treatment of cancer. As a result, MPS1 inhibitors have been pursued by a number of organizations, and accordingly, at least four compounds have reached Phase 1 clinical trials:
BAY1161909 (1), ${ }^{14}$ BAY1217389 (2), ${ }^{14}$ CFI-402257 (3), ${ }^{15}$ and S 81694 (structure undisclosed). We recently reported advanced inhibitors including CCT251455 (4) ${ }^{16}$ and a series of pyrido $[3,4-d]$ pyrimidines $(34 \mathrm{~h}(5))^{17}$ (Figure 1 ).

While the single agent efficacy of MPS1 inhibitors has been described to be limited, ${ }^{18-21}$ a number of recent reports have documented that inhibition of MPS1 is particularly effective when used in combination with other drugs, for example, tubulin-targeting agents or CDK4/6 inhibitors. ${ }^{22-26}$ We were particularly intrigued by the use of MPS1 inhibitors in combination with paclitaxel for triple negative breast cancer. Paclitaxel is often used for this aggressive and highly

Received: May 1, 2018

Published: September 10, 2018 


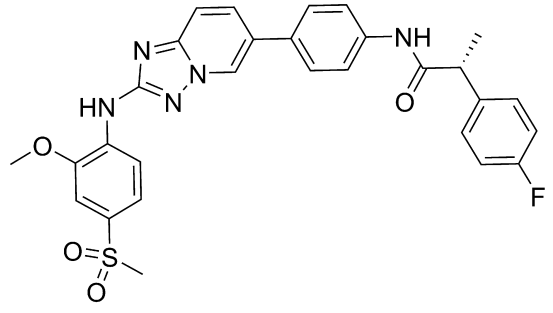

BAY1161909 (1)<smiles>COc1ccc(Oc2cc(NCCC(F)(F)F)c3ncc(-c4ccc(C(=O)NC5CC5)c(C)c4)n3n2)c(F)c1F</smiles>

BAY1217389 (2)<smiles>Cc1cc(-c2cnn3c(NC[C@H]4C[C@H](O)C4)cc(Oc4cccnc4)nc23)ccc1C(=O)NC1CC1</smiles>

CFI-402257 (3)<smiles>Cn1cc(-c2cc3cnc(Nc4ccc(-c5cncn5C)cc4Cl)cc3n2C(=O)OC(C)(C)C)cn1</smiles>

CCT251455 (4)<smiles>COc1cc(-c2cnn(C)c2)ccc1Nc1ncc2ccnc(N[C@@H](C)C(C)(C)C)c2n1</smiles>

$34 \mathrm{~h}(5)$

Figure 1. Published MPS1 inhibitors.

proliferative cancer but, on its own, does frequently not lead to durable responses, particularly in the metastatic setting. ${ }^{27}$ Triple negative breast cancer thus remains a high medical need, and new effective therapeutic regimens are needed.

The work presented here builds upon a series of pyrido[3,4$d]$ pyrimidines that we recently disclosed. ${ }^{17}$ Advanced compounds in this series showed excellent potency in biochemical and cellular assays, exemplified by 5 (Figure 2); which was

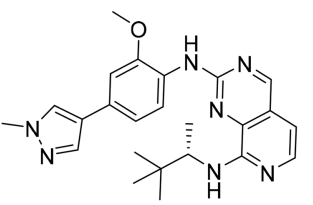

$$
\begin{gathered}
\mathbf{5} \\
\text { MPS1 1mM ATP IC } \mathrm{I}_{50}=20.0 \pm 13.0 \mathrm{nM} \\
\text { CDK2 IC } \mathrm{IS}_{50}=0.56 \mu \mathrm{M} \\
\text { P-MPS1 IC } 50=59.0 \mathrm{nM} \\
\text { Mouse } \mathrm{Cl}_{\text {int }}=43.3 \mu \mathrm{L} / \mathrm{min} / \mathrm{mg} \text { protein } \\
\text { Human } \mathrm{Cl}_{\text {int }}=151.2 \mu \mathrm{L} / \mathrm{min} / \mathrm{mg} \text { protein } \\
\text { ALogP }=4.67 \\
\text { Solubility }=0.8 \mu \mathrm{M}
\end{gathered}
$$

Figure 2. MPS1 inhibitor 5. "P-MPS1" indicates an electrochemiluminescence mesoscale discovery (MSD)-based cellular assay that measured autophosphorylation of ectopically expressed MPS1 in HCT 116 cells. Solubility conditions: HPLC, 1\% DMSO, 10 mM PBS, $\mathrm{pH}$ 7.4.

effective in inhibiting MPS1 in vivo. ${ }^{17}$ However, this series in general, and $\mathbf{5}$ in particular, suffered from key liabilities that prevented further development, specifically high turnover in human microsomes as well as excessive lipophilicity.

Herein, we describe our optimization of the pyrido[3,4d] pyrimidine series $^{17}$ culminating in the discovery of a Phase 1 clinical candidate compound.

\section{CHEMISTRY}

Des methyl pyrido[3,4- $d]$ pyrimidine compounds were made using the route shown in Scheme 1. Two complementary approaches could be used to gain access to the des methyl compounds. First, the amine was introduced into 7 by displacement of the chloride, followed by $m$-CPBA oxidation to give sulfone 9. Displacement of the sulfone with the appropriate formamide under $\mathrm{NaH} / \mathrm{THF}$ conditions gave rise to the desired des methyl pyrido[3,4- $d]$ pyrimidine compounds (Scheme 1). Alternatively, the steps could be reversed, carrying out the $m$-CPBA oxidation as the first step to afford sulfone $\mathbf{1 8}$. Displacement with the appropriate formamide could then be carried out as previously, before introducing the amine at the final step, through reaction of the chloro-intermediate $\mathbf{2 0}$ with neopentylamine in NMP at elevated temperatures.

Compounds in the 6-methyl pyrido $[3,4-d]$ pyrimidine series were prepared from the key intermediate 8-chloro-2(methylthio)pyrido[3,4- $d]$ pyrimidine 22, the synthesis of which we have previously reported. ${ }^{28}$ Treatment of this intermediate with an amine at elevated temperature in NMP gave rise to sulfides 23-25. Oxidation of these compounds with $m$-CPBA afforded sulfones 26-28, which were ideally set up to undergo selective displacement. The aniline moiety was introduced using the corresponding formamide with either $\mathrm{NaH}$ in THF or cesium carbonate in DMSO, affording the desired 6-methyl pyrido[3,4-d]pyrimidines 34-42 (Scheme 2).

Again the order of steps could be reversed with the oxidation with $m$-CPBA being carried out first to give sulfone 43, which could then undergo the same coupling with the appropriate formamide as previously described using $\mathrm{NaH}$ in THF. Displacement of the chloro intermediate $\mathbf{4 4}$ was then carried out with amines at elevated temperatures in NMP (Scheme 3).

All amines used were commercially available, and the formamides were synthesized from the corresponding anilines by refluxing in formic acid. The anilines were prepared by standard transformations (see Supporting Information for procedures).

\section{RESULTS AND DISCUSSION}

We routinely tested our compounds in a caliper-based MPS1 kinase assay at $1 \mathrm{mM}$ ATP. As described in our preceding publication, $^{17}$ this relatively high ATP concentration was 


\section{Scheme $1^{a}$}

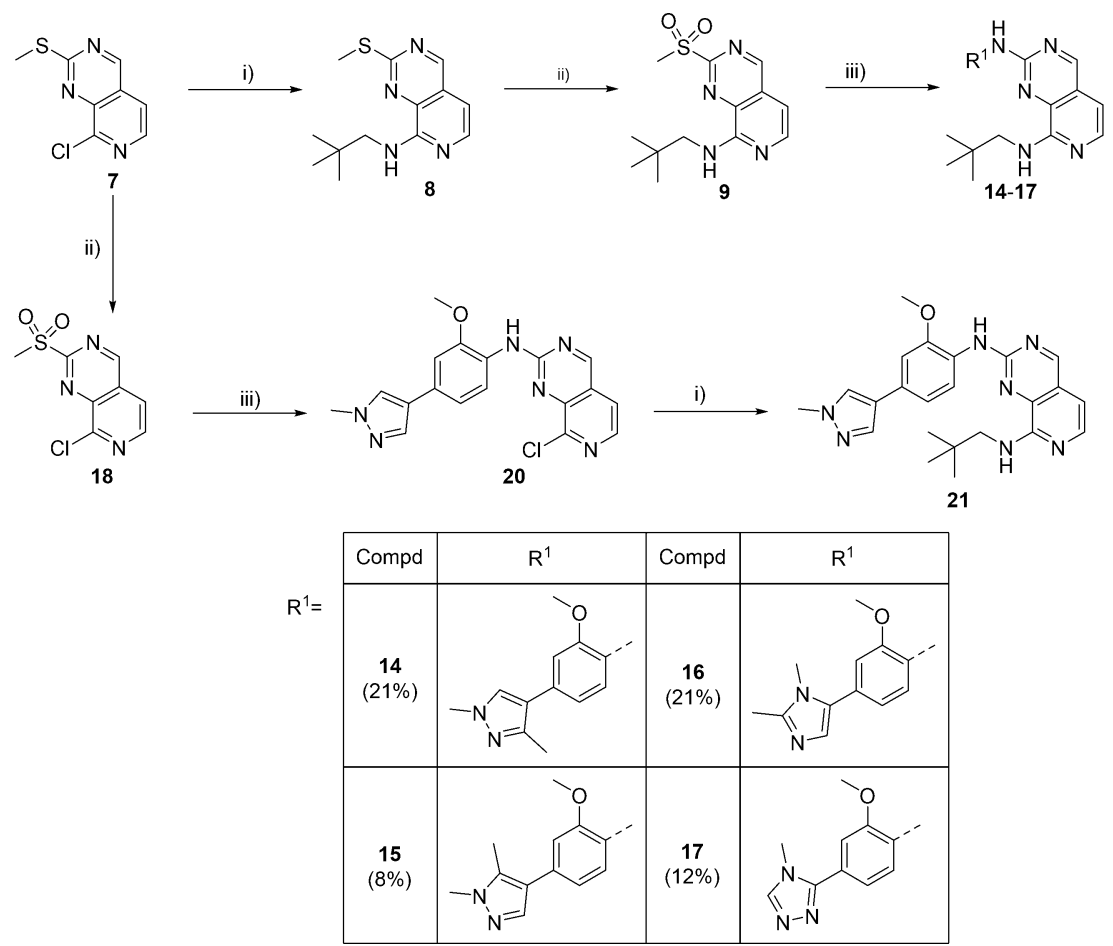

${ }^{a}$ Reagents and conditions: (i) amine, NMP, $100-130{ }^{\circ} \mathrm{C}$; (ii) $m$-CPBA, $\mathrm{CH}_{2} \mathrm{Cl}_{2}, 0{ }^{\circ} \mathrm{C}-$ r.t.; (iii) ArNHCHO $10-13$ or 19, NaH, THF, $0{ }^{\circ} \mathrm{C}-$ r.t.

necessary due to the high potency of advanced compounds $\left(K_{\mathrm{i}} \mathrm{s}<1 \mathrm{nM}\right)$ that was beyond the dynamic range of the assay at lower ATP concentrations. Furthermore, we progressed compounds of sufficient potency to an MSD-based cellular assay that measured autophosphorylation of ectopically expressed MPS1 in HCT116 cells. ${ }^{16}$ In addition, we routinely determined selectivity against $\mathrm{CDK} 2$, a cell cycle kinase with a high homology to MPS1 in terms of the ATP binding domain. Since the CDK2 assay was run at much lower ATP concentrations, we converted the $\mathrm{IC}_{50}$ values from the MPS1 assay (at $1 \mathrm{mM} \mathrm{ATP}$ ) and those from the CDK2 assay (at 10 $\mu \mathrm{M}$ ATP) into $K_{\mathrm{i}}$ values and used these calculated $K_{\mathrm{i}} \mathrm{s}$ to assess the selectivity ratio.

Our key goal for the optimization of the pyrido[3,4- $d]$ pyrimidines series was to significantly improve the low human liver microsomal stability observed for compound $\mathbf{5}$ and other compounds in this series. Extensive attempts to identify major metabolites showed multiple oxidations and dealkylation products but failed to identify a consistent site of metabolism. Furthermore, we had not observed a correlation between stability in human microsomes and lipophilicity indicating that lowering $\log \mathrm{P}$ was not a promising approach. We thus suspected that rapid turnover was driven by recognition of a specific pharmacophore within our series and decided to systematically derivatize the molecule to discover modifications that would block this recognition and increase the metabolic stability.

We started by altering the five-membered ring heterocycle of 5 maintaining a neopentyl substituent in the 8-position of the pyrido $[3,4-d]$ pyrimidine core. These compounds are summarized in Table 1. Methylated and dimethylated pyrazole containing compounds $(\mathbf{2 1}, \mathbf{1 4}$, and $\mathbf{1 5})$ showed only relatively modest activity in the high ATP assay, as well as in the cellular assay. The imidazole substituted compound (16) demon- strated excellent levels of biochemical activity, as well as showing promising levels of selectivity over CDK2 and cellular activity. Finally, triazole containing 17, while exhibiting nanomolar potency for CDK2, stood out in terms of its single digit nanomolar potency in the cellular assay and represents one of the most potent MPS1 inhibitors known to us. In fact, the potency of this compound was beyond the lower range of our biochemical assay even at $1 \mathrm{mM}$ ATP. The reason why replacing the pyrazole moiety in $\mathbf{2 1}$ with imidazole (15) and particularly triazole (16) significantly boosted biochemical activity remained unclear, and crystal structures (vide infra) did not provide any additional insights.

We tested the human liver microsome (HLM) stability of compounds 16 and 17, but both still underwent extensive metabolism showing $\mathrm{Cl}_{\text {int }}$ values of 79 and $92 \mu \mathrm{L} / \mathrm{min} / \mathrm{mg}$ protein, respectively. Nevertheless, the comparably low molecular weight (418) and lipophilicity (3.6) made 17 an excellent starting point for further investigation, and we decided to improve CDK2 selectivity and HLM stability.

In order to develop hypotheses on how to reduce CDK2 activity, we superimposed X-ray structures of our compounds ${ }^{17}$ with published CDK2 structures (Figure 3). ${ }^{29,30}$

Fourteen residues are different within the ATP binding pockets of MPS1 and CDK2, including the gatekeeper residue, which is Met602 in MPS1 and a bulkier phenylalanine (Phe80) in CDK2 (Figure 3). We hypothesized that introducing a methyl group at the 6-position of the pyrido $[3,4-d]$ pyrimidine core would be less tolerated in CDK2 than in MPS1, due to a clash with the CDK2 Phe80 gatekeeper residue.

We thus set out to prepare a series of methyl substituted compounds. The significant investigations required to access pyrido $[3,4-d]$ pyrimidines with substitution in this position were disclosed by us recently. ${ }^{28}$ 
Scheme $2^{a}$
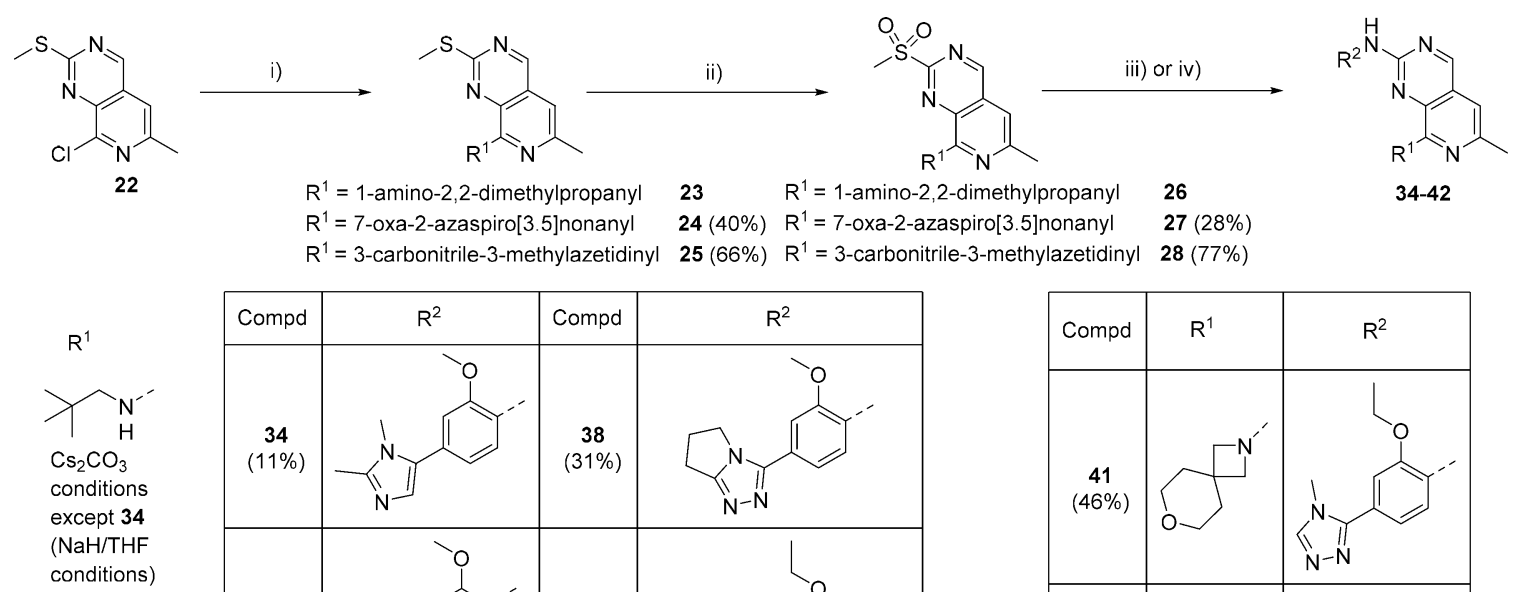

\begin{tabular}{|c|c|c|c|}
\hline Compd & $R^{2}$ & Compd & $\mathrm{R}^{2}$ \\
\hline $\begin{array}{c}34 \\
(11 \%)\end{array}$ & & $\begin{array}{c}38 \\
(31 \%)\end{array}$ & \\
\hline $\begin{array}{c}35 \\
(48 \%)\end{array}$ & & $\begin{array}{c}39 \\
(35 \%)\end{array}$ & \\
\hline $\begin{array}{c}36 \\
(70 \%)\end{array}$ & & $\begin{array}{c}40 \\
(18 \%)\end{array}$ & \\
\hline $\begin{array}{c}37 \\
(56 \%)\end{array}$ & & & \\
\hline & & & \\
\hline
\end{tabular}

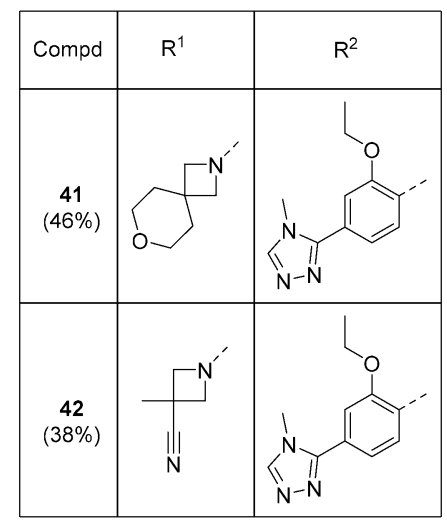

${ }^{a}$ Reagents and conditions: (i) amine, NMP, $100-130{ }^{\circ} \mathrm{C}$; (ii) $\mathrm{m}$-CPBA, $\mathrm{CH}_{2} \mathrm{Cl}_{2}, 0{ }^{\circ} \mathrm{C}-$ r.t.; (iii) $\operatorname{ArNHCHO} 12,13$, or $29-33, \mathrm{NaH}$, THF, $0{ }^{\circ} \mathrm{C}-$ r.t.; (iv) $\mathrm{ArNHCHO}, \mathrm{Cs}_{2} \mathrm{CO}_{3}, \mathrm{DMSO}, 120{ }^{\circ} \mathrm{C}$.

Scheme $3^{a}$

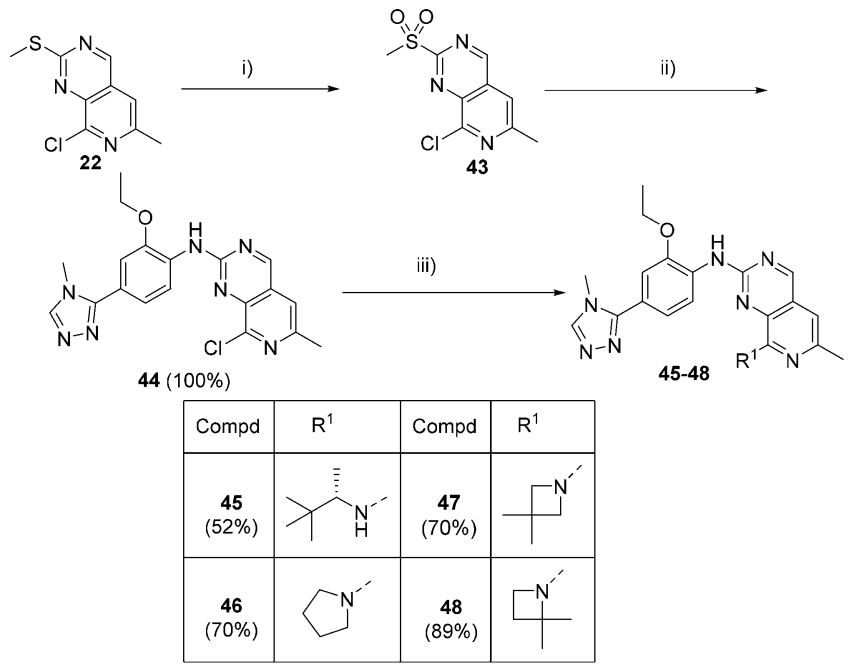

${ }^{a}$ Reagents and conditions: (i) $m$-CPBA, $\mathrm{CH}_{2} \mathrm{Cl}_{2}, 0{ }^{\circ} \mathrm{C}-$ r.t.; (ii) ArNHCHO 29, NaH, THF, $0{ }^{\circ} \mathrm{C}-$ r.t.; (iii) amine, NMP, 100-130 ${ }^{\circ} \mathrm{C}$.

Table 2 shows the biochemical and cellular results for two initial proof-of-concept compounds made as matched pairs to the corresponding unsubstituted compounds (16 and 17). Both compounds show potent biochemical inhibition of MPS1 and lower but still acceptable levels of inhibition in cells. As hypothesized, both 6-methylated compounds (34 and 35) demonstrated a significant improvement in selectivity for MPS1 over CDK2 ( $K_{\mathrm{i}}$ ratio is between 500 and 7600). Even more importantly and somewhat unexpectedly, we observed a large improvement in HLM metabolism for the 6-methylated compounds. Compounds 34 and 35 represented by far the most stable compounds we had observed and thus a breakthrough in terms of optimizing the up to this point persisting HLM liability. We thus decided to focus on the methylated amino-pyrido $[3,4-d]$ pyrimidine core.

To understand why these compounds showed greatly improved stability, we identified the metabolites for the matched pair 17 and 35. Interestingly, these experiments showed that the introduction of the methyl group completely changed the nature of the main metabolites in HLM (Figure 4). Incubation of compound 17 with HLM primarily led to metabolites in which the triazole and aniline moieties were oxidized (Figure 4). In sharp contrast, treatment of 35 with HLM led to oxidation on the neopentyl chain followed by loss of the entire chain (Figure 4). Importantly, the metabolic hotspots are not only different for these compounds but, in both cases, also distant from the position of the newly introduced methyl group of 35. This observation thus suggests that the reduction of HLM metabolism is not due to blocking of a metabolically labile position (a commonly applied strategy, particularly using fluorine atoms) but instead to blocking of the 
Table 1. Biochemical and Cellular Data for Aniline Modifications on Neopentyl-Substituted Core ${ }^{a}$

16 Compd

${ }^{a}$ Results are in $\mathrm{nM}$ unless otherwise stated and are mean for $n \geq 3$, or mean values of two independent determinations or samples run $n=1$. For SD (for $n \geq 3$ ) and individual determinations $(n=2)$, see Table S1. "P-MPS1" indicates an electrochemiluminescence mesoscale discovery (MSD)based cellular assay that measured autophosphorylation of ectopically expressed MPS1 in HCT116 cells. $K_{\mathrm{i}} \mathrm{s}$ were calculated from the IC $\mathrm{C}_{50} \mathrm{~s}$ using the Cheng-Prusoff equation.

pharmacophore through which $\mathbf{1 7}$ is recognized and bound. This hypothesis is consistent with the nature of P450 enzymes where substrate recognition and catalytic sites are spatially separated.

Compound 35 thus represented a significant step forward, and we explored whether HLM stability, CDK2 selectivity, cellular potency, and solubility could be further optimized. Table 3 summarizes modifications of the methoxy group and the triazole ring substituents. Based on existing SAR, we hypothesized that introducing an ethoxy group in place of the methoxy group of 35 improves selectivity further. The corresponding ethoxy compound (36) showed similar levels of biochemical potency $\left(\mathrm{IC}_{50} 11 \mathrm{vs} 13 \mathrm{nM}\right)$, albeit with a slight drop in cellular potency (P-MPS1 $\mathrm{IC}_{50} 63$ vs $30 \mathrm{nM}$ ). As hypothesized, this transformation resulted in an improved selectivity window over CDK2 $\left(K_{\mathrm{i}}\right.$ ratio $500(35)$ vs $\left.46(36)\right)$ and significantly improved stability in HLM.

Introduction of a methyl group onto the triazole ring (37) resulted in very similar levels of potency to 35 both in the biochemical and cellular assays (Table 3), albeit with an increase in lipophilicity $(\mathrm{ALogP}=4.49$ vs 3.88$)$. The bicyclic triazole derivatives 38 and 39 were also potent biochemical inhibitors but showed significantly weaker inhibition in cells.
Interestingly, this matched pair (38 and 39) also demonstrated a similar increase in selectivity between methoxy and ethoxy derivatives. Finally, adding a basic dimethylamino group to improve solubility (40) resulted in loss of cellular potency (PMPS1 IC $50230 \mathrm{nM}$ ) possibly due to a decrease in cellular permeability of the more polar dimethylamine tail group, though the solubility (77.6 $\mu \mathrm{M}$ [HPLC method, 1\% DMSO, $10 \mathrm{mM}$ PBS, $\mathrm{pH}$ 7.4]) of this compound was greatly improved in comparison to 35 .

From this investigation, 36 emerged as an attractive compound, and we tested if the overall properties could be further optimized by modification of the neopentyl amine.

Table 4 shows a representative set of amine substitutions at the 8-position of the pyrido[3,4- $d]$ pyrimidine core. Compound 45 bears the same branched primary amine used in our previously reported MPS1 inhibitor $5 .{ }^{17}$ Compound 45 demonstrated good activity against MPS1 in the biochemical and cellular assays (Table 4) but exhibits poor solubility (2.2 $\mu \mathrm{M}$ ), a possible consequence of the increased ALogP (4.61). The introduction of secondary amines including pyrrolidine (46) and substituted azetidines (47, 48, and 42) exhibited varied activity against MPS1. Pyrrolidine containing 46 displayed a significant decrease in the biochemical and cellular 


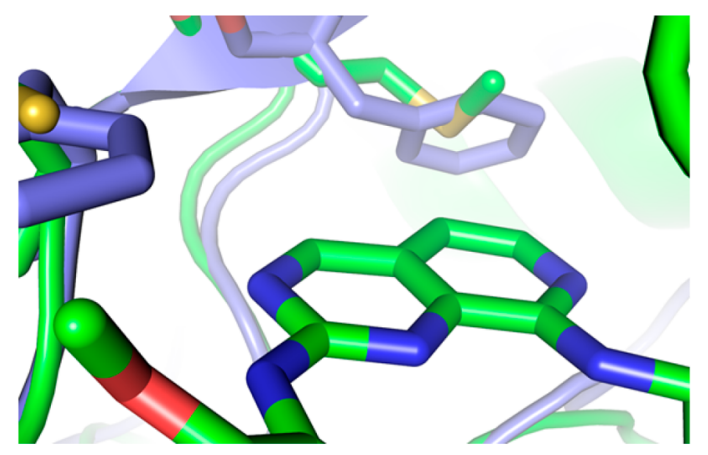

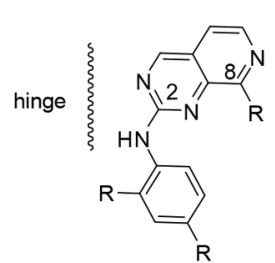

8-substituted 2-anilinopyrido[3,4- d]pyrimidines

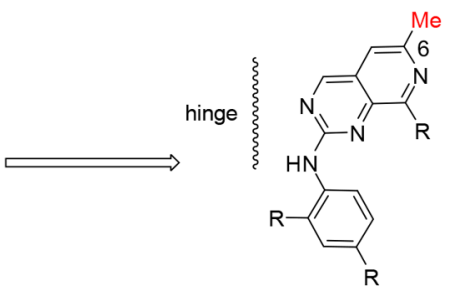

6-methyl 8-substituted 2-anilinopyrido[3,4- $d$ ]pyrimidines
Figure 3. Top: Superimposed crystal structure of MPS1 (green) bound to a pyrido $[3,4-d]$ pyrimidine core (carbon atoms colored green), extracted from PDB code 5EH0, onto the structure of CDK2 (blue), extracted from PDB code $1 \mathrm{H} 08$ (ligand hidden for clarity), showing the different gatekeeper residues present in MPS1 and CDK2. Bottom: 6-position methyl group on pyrido[3,4-d]pyrimidine core.<smiles>COc1cc(-c2nncn2C)ccc1Nc1ncc2cccnc2c1NCC(C)(C)[In]</smiles>

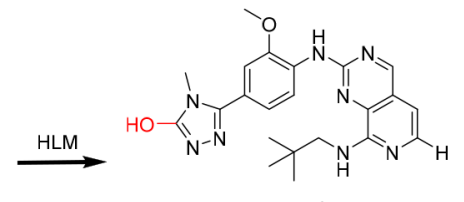

17<smiles>COc1cc(Nc2ncc3cc(C)nc(NCC(C)(C)C)c3n2)ccc1-c1nncn1C</smiles>

$\stackrel{\mathrm{HLM}}{\longrightarrow}$<smiles>COc1ccc(-c2nnnn2C)c(Nc2ncc3cc(C)nc(NC(O)C(C)(C)C)c3n2)c1</smiles>

Figure 4. Results of a Met ID study showing oxidation products for the match pair of compounds $\mathbf{1 7}$ and $\mathbf{3 5}$ after treatment with HLM.

potency observed. Compound 47 exhibited excellent activity (P-MPS1 IC $\mathrm{IC}_{50} 37 \mathrm{nM}$ ) and good levels of selectivity over CDK2 coupled with an increased solubility of $31.5 \mu \mathrm{M}$, possibly due to the decreased ALogP of 3.85. However, movement of the gem dimethyl group one carbon round the ring into the $\alpha$-position (48) resulted in loss of all MPS1 activity (P-MPS1 $\mathrm{IC}_{50} 3.8 \mu \mathrm{M}$ ). Cyano-substituted azetidine compound (42) also showed acceptable levels of potency (PMPS1 IC $50110 \mathrm{nM}$ ) and selectivity over CDK2 (CDK2 $\mathrm{IC}_{50}$

Table 2. Biochemical and Cellular Data for Two Matched Pairs of Compounds Containing H or Me at the 6-Position of the Pyrido[3,4-d] pyrimidine Core ${ }^{a}$

\begin{tabular}{|c|c|c|c|c|c|c|c|c|c|}
\hline \multirow{3}{*}{ Compd } & \multirow{3}{*}{ Structure } & \multicolumn{4}{|c|}{ Biochemical activity } & \multirow{3}{*}{$\begin{array}{c}\text { P-MPS1 } \\
\text { IC }_{50}\end{array}$} & \multirow{3}{*}{$A \log P$} & \multicolumn{2}{|c|}{$\begin{array}{c}\mathrm{Cl}_{\text {int }} \\
(\mu \mathrm{L} / \mathrm{min} / \mathrm{mg} \\
\text { protein) }\end{array}$} \\
\hline & & \multicolumn{2}{|c|}{ MPS1 } & \multicolumn{2}{|c|}{ CDK2 } & & & & \\
\hline & & $\mathrm{IC}_{50}$ & $\mathrm{~K}_{\mathrm{i}}$ & $\mathrm{IC}_{50}$ & $\mathrm{~K}_{\mathrm{i}}$ & & & Hivase & пиппап \\
\hline 16 & & 8.5 & 0.084 & 86 & 43 & 44 & 4.27 & 92.5 & 79.4 \\
\hline 34 & & 9.5 & 0.094 & 1,400 & 720 & 170 & 4.55 & 34.5 & 28.2 \\
\hline 17 & & 6.8 & 0.067 & 16 & 8.0 & 3.5 & 3.60 & 81.5 & 92.1 \\
\hline 35 & & 13 & 0.13 & 130 & 65 & 30 & 3.88 & 41.1 & 23.8 \\
\hline
\end{tabular}

${ }^{a}$ Results are in $\mathrm{nM}$ unless otherwise stated and are mean for $n \geq 3$, or mean values of two independent determinations or samples run $n=1$. For SD (for $n \geq 3$ ) and individual determinations $(n=2)$, see Table S2. "P-MPS1" indicates an electrochemiluminescence mesoscale discovery (MSD)based cellular assay that measured autophosphorylation of ectopically expressed MPS1 in HCT116 cells. $K_{\mathrm{i}} \mathrm{s}$ were calculated from the IC $\mathrm{C}_{50} \mathrm{~s}$ using the Cheng-Prusoff equation. 
Table 3. Biochemical and Cellular Data for Triazole Modifications Based on $35^{a}$

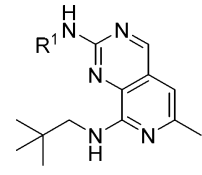

\begin{tabular}{|c|c|c|c|c|c|c|c|c|c|c|}
\hline \multirow{3}{*}{ Compd } & \multicolumn{5}{|c|}{ Biochemical activity } & \multirow{3}{*}{$\begin{array}{c}\text { P-MPS1 } \\
\text { IC }_{50}\end{array}$} & \multirow{3}{*}{$A \log P$} & \multicolumn{2}{|c|}{$\begin{array}{c}\mathrm{Cl}_{\text {int }} \\
(\mu \mathrm{L} / \mathrm{min} / \mathrm{mg} \\
\text { protein) }\end{array}$} & \multirow{3}{*}{$\begin{array}{c}\text { Solubility } \\
\boldsymbol{\mu M}\end{array}$} \\
\hline & & \multicolumn{2}{|c|}{ MPS1 } & \multicolumn{2}{|c|}{ CDK2 } & & & & & \\
\hline & & $\mathrm{IC}_{50}$ & $\mathrm{~K}_{\mathrm{i}}$ & $\mathrm{IC}_{50}$ & $\mathrm{~K}_{\mathrm{i}}$ & & & & & \\
\hline 35 & & 13 & 0.13 & 130 & 65 & 30 & 3.88 & 41.1 & 23.8 & 8.6 \\
\hline 36 & & 11 & 0.11 & 1,020 & 510 & 63 & 4.23 & 26.3 & 8.0 & 6.6 \\
\hline 37 & & 12 & 0.12 & 940 & 470 & 33 & 4.49 & 32.9 & 20.4 & 1.8 \\
\hline 38 & & 19 & 0.19 & 250 & 130 & 240 & 4.40 & 28.8 & 28.8 & 1.7 \\
\hline 39 & & 38 & 0.38 & $>10,000$ & $>5,000$ & 250 & 4.75 & 36.4 & 18.6 & nd \\
\hline 40 & & 12 & 0.12 & 360 & 180 & 230 & 4.75 & 27.7 & 23.0 & 77.6 \\
\hline
\end{tabular}

${ }^{a}$ Results are in $\mathrm{nM}$ unless otherwise stated and are mean for $n \geq 3$, or mean values of two independent determinations or samples run $n=1$. For SD (for $n \geq 3$ ) and individual determinations $(n=2)$, see Table S3. "P-MPS1" indicates an electrochemiluminescence mesoscale discovery (MSD)based cellular assay that measured autophosphorylation of ectopically expressed MPS1 in HCT116 cells.

$2.70 \mu \mathrm{M})$, combined with a much lower AlogP of 3.25 . However, this reduced ALogP did not translate into increased solubility, with 42 only showing a solubility of $6.8 \mu \mathrm{M}$. Introduction of a polar spirocyclic amine (41) resulted in a dramatic drop in lipophilicity $(\operatorname{Alog} P=3.08)$, which, as expected, translated into an increase in solubility $(56.2 \mu \mathrm{M})$.

To understand the observed MPS1 SAR (Table 4), we solved the crystal structure of compound 36 bound to MPS1 (Figure 5A). As expected, the binding mode of 36 was nearly identical to that of the previously described pyrido[3,4$d]$ pyrimidine inhibitors. ${ }^{17}$ The pyrido $[3,4-d]$ pyrimidine scaffold of 36 binds to the hinge region, the 6-methyl group important for CDK2 selectivity and for the reduction in HLM metabolism, is located close to the side chain of the gatekeeper residue Met602, and the ethoxy moiety also important for selectivity binds in the selectivity pocket above the hinge. Somewhat surprisingly, the triazole moiety was not engaged in a hydrogen bond, and thus the X-ray structure did not explain why replacing the pyrazole of $\mathbf{2 1}$ with triazole (17, Table 1) led to a significant increase in activity (vide supra). Together with previously reported structures of CCT251455 (4) and (5), the $\mathrm{X}$-ray structure of 36 allowed us to rationalize the SAR summarized in Table 4. As previously described for compound 5, the neopentyl chain binds to a hydrophobic pocket that is created by a reordering of the MPS1 activation loop into an inactive conformation (Figure 5B). ${ }^{16,17}$ The shape of the neopentyl chain represents an excellent match to this pocket resulting in several hydrophobic contacts explaining why this moiety is critical for activity. The two azetidine derivatives $\mathbf{4 7}$ and 48 exemplify the importance of the correct shape of the amine substituent for potent inhibition. The 3,3-dimethylazetidine substituent of derivative 47 can be regarded as a constrained mimetic of the neopentyl chain that can likely engage in similar hydrophobic contacts, and 47 maintains potent inhibition. The 2,2-dimethylazetidine moiety of 48, however, differs significantly in its overall shape from the neopentyl chain leading to less favorable interactions and a 40fold higher $\mathrm{IC}_{50}$.

To investigate which of the potent and selective compounds in Table 4 can be progressed further, we tested the stability in liver microsomes. Gratifyingly, all compounds tested showed satisfactory stability $\left(\mathrm{Cl}_{\text {int }}<45 \mu \mathrm{L} / \mathrm{min} / \mathrm{mg}\right.$ protein in mouse and $\mathrm{Cl}_{\text {int }}<26 \mu \mathrm{L} / \mathrm{min} / \mathrm{mg}$ protein in human) (Table 4). This represented a vast improvement over the human intrinsic 
Table 4. Biochemical and Cellular Data for Amine Modifications Based on $36^{a}$

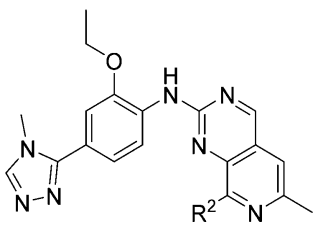

\begin{tabular}{|c|c|c|c|c|c|c|c|c|c|c|}
\hline \multirow{3}{*}{ Compd } & \multirow{3}{*}{$\mathbf{R}^{2}$} & \multicolumn{4}{|c|}{ Biochemical activity } & \multirow{3}{*}{$\begin{array}{c}\text { P-MPS1 } \\
\text { IC }_{50}\end{array}$} & \multirow{3}{*}{$A \log P$} & \multicolumn{2}{|c|}{$\begin{array}{c}\mathrm{Cl}_{\text {int }} \\
(\mu \mathrm{L} / \mathrm{min} / \mathrm{mg} \\
\text { protein })\end{array}$} & \multirow{3}{*}{$\begin{array}{c}\text { Solubility } \\
\boldsymbol{\mu M}\end{array}$} \\
\hline & & \multicolumn{2}{|c|}{$\begin{array}{c}\text { MPS1 (1 mM } \\
\text { ATP) }\end{array}$} & \multicolumn{2}{|c|}{ CDK2 } & & & mouse & human & \\
\hline & & $\mathrm{IC}_{50}$ & $\mathrm{~K}_{\mathrm{i}}$ & $\mathrm{IC}_{50}$ & $\mathrm{~K}_{\mathrm{i}}$ & & & & & \\
\hline 36 & & 11 & 0.11 & 1,020 & 510 & 63.0 & 4.23 & 26.3 & 8.0 & 6.6 \\
\hline 45 & & 4.7 & 0.047 & 150 & 77 & 23.0 & 4.61 & 25.3 & 15.2 & 2.2 \\
\hline 46 & & 83 & 0.82 & 1,100 & 550 & 370 & 3.58 & nd & nd & nd \\
\hline 47 & & 8.9 & 0.088 & 1,600 & 810 & 37 & 3.85 & 44.3 & 25.2 & 31.5 \\
\hline 48 & $\Gamma$ & 400 & 4.0 & 26,000 & 13,000 & 3,800 & 3.58 & nd & nd & nd \\
\hline 42 & & 20 & 0.20 & 2,700 & 1,400 & 110 & 3.25 & 24.7 & 5.6 & 6.8 \\
\hline 41 & & 11 & 0.11 & 2,500 & 1,300 & 37 & 3.08 & 32.9 & 9.4 & 56.2 \\
\hline
\end{tabular}

${ }^{a}$ Results are in $\mathrm{nM}$ unless otherwise stated and are mean for $n \geq 3$, or mean values of two independent determinations or samples run $n=1$. For SD (for $n \geq 3$ ) and individual determinations $(n=2)$, see Table S4. "P-MPS1" indicates an electrochemiluminescence mesoscale discovery (MSD)based cellular assay that measured autophosphorylation of ectopically expressed MPS1 in HCT116 cells.
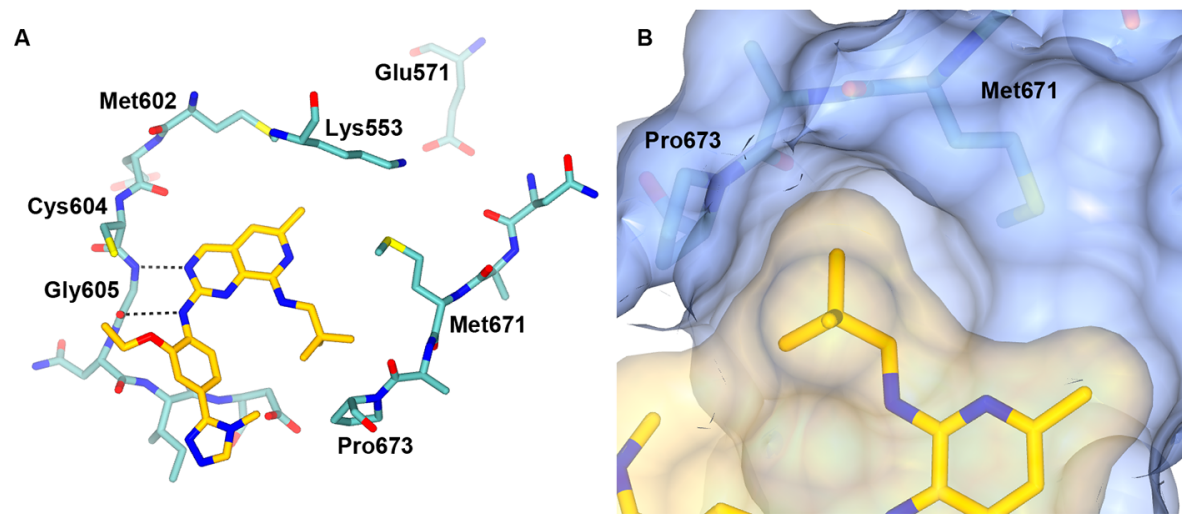

Figure 5. (A) Crystal structure of 36 bound to MPS1 (pdb code 6H3K). Compound 36 is shown with carbon atoms in yellow. Selected amino acids are shown in sea green and are labeled. Key hydrogen bonds are indicated as black dotted lines. (B) Close up of the neopentyl binding pocket. The neopentyl substituent is enveloped by residues Met671 and Pro673 from the activation loop. Protein surface is displayed as a transparent blue surface. The compound surface is shown in transparent yellow. 
Table 5. Mouse and Rat Blood Pharmacokinetics of 36, 41, 45, and 47 at $5 \mathrm{mg} / \mathrm{kg}$ iv and po, unless Otherwise Stated ${ }^{a, b, c}$

\begin{tabular}{|c|c|c|c|c|c|c|c|c|c|}
\hline Compd & Structure & species & $\mathbf{t}_{1 / 2}(\mathbf{h})$ & $\mathrm{Cl}(\mathrm{mL} / \mathrm{min} / \mathrm{kg})$ & $\begin{array}{c}\mathrm{Cmax}_{\mathrm{po}} \\
(\mathrm{nmol} / \mathrm{L})\end{array}$ & $\mathrm{AUC}_{\mathrm{po}}(\mathrm{h} * \mathrm{nmol} / \mathrm{L})^{\mathrm{d}}$ & PPB (\%) & $\mathrm{V}_{\mathrm{ss}}(\mathrm{L} / \mathbf{k g})$ & F (\%) \\
\hline \multirow[t]{2}{*}{36} & & mouse & 2.68 & 10.9 & 2757 & 11000 & 99.85 & 2.46 & 81 \\
\hline & & $\mathrm{rat}^{\mathrm{a}}$ & 4.66 & 10.1 & 813 & 11325 & nd & 3.52 & 63 \\
\hline \multirow[t]{2}{*}{41} & & mouse & 0.66 & 22.6 & 3083 & 4779 & 98.09 & 1.21 & 63 \\
\hline & & rat & 1.5 & 7.59 & 1181 & $5156^{\mathrm{e}}$ & nd & 0.89 & 22 \\
\hline \multirow[t]{2}{*}{45} & & mouse & 3.47 & 8.40 & 2923 & 13764 & 99.91 & 2.19 & 86 \\
\hline & & $\mathrm{rat}^{\mathrm{b}}$ & 4.52 & 6.00 & 1893 & 273000 & nd & 1.88 & 92 \\
\hline \multirow[t]{2}{*}{47} & & mouse & 1.58 & 16.3 & 2348 & 8110 & 99.28 & 2.09 & 75 \\
\hline & & rat & 3.03 & 7.35 & 1417 & 18335 & nd & 1.88 & 72 \\
\hline
\end{tabular}

$a_{2.5} \mathrm{mg} / \mathrm{kg}$ (iv). ${ }^{b} 1 \mathrm{mg} / \mathrm{kg}$ (iv). ${ }^{c}$ Compounds were administered iv and po (Mouse, $0.1 \mathrm{~mL} / 10 \mathrm{~g}$ in $10 \%$ DMSO, $5 \%$ Tween 20 in saline; Rat, 0.05 $\mathrm{mL} / 10 \mathrm{~g}$ in $10 \% \mathrm{DMSO}, 5 \%$ Tween 20 in saline). ${ }^{d} \mathrm{AUC}_{\text {last }} 6 \mathrm{~h}$ for mouse, $24 \mathrm{~h}$ for rat, unless otherwise stated. ${ }^{e} \mathrm{AUC}_{\text {last }} 6 \mathrm{~h}$.

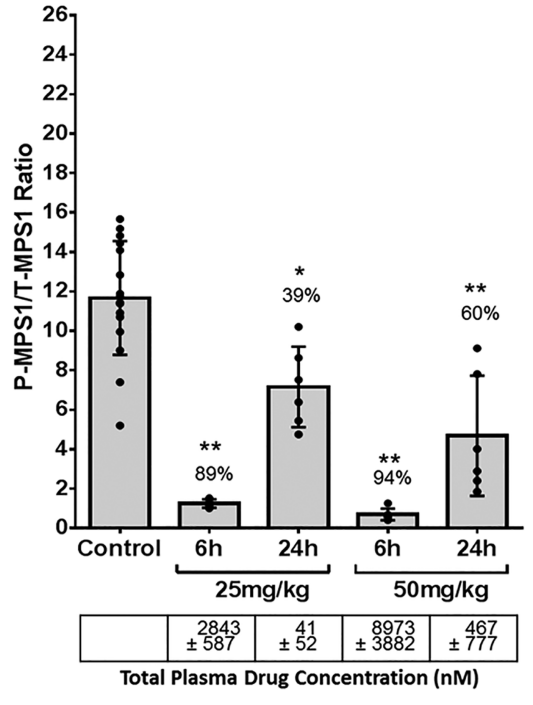

Compound 36

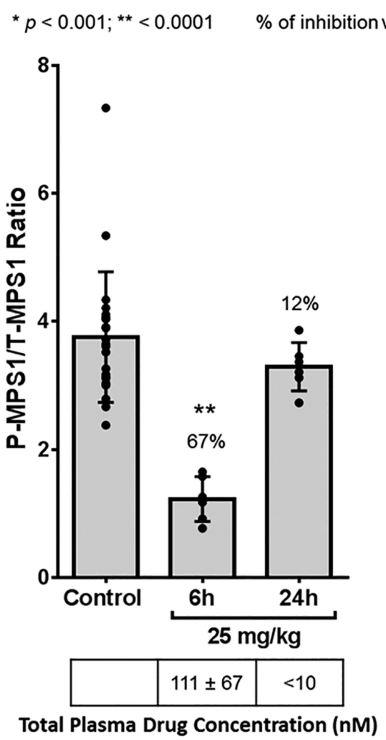

Compound 41

Figure 6. Bar charts show the ratio of phosphylated-MPS1/total-MPS1 levels (gray) in the Dox-DLD1 model after treatment with 36 (left) and 41 (right) at specified doses and time points. The plasma levels at the respective time points are given in the table below the bar chart.

clearance values seen for compound $5\left(\mathrm{Cl}_{\text {int }} 151.2 \mu \mathrm{L} / \mathrm{min} / \mathrm{mg}\right.$ protein), the starting point of our investigation.

With a number of active, selective, and soluble compounds in hand, we decided to investigate the mouse and rat pharmacokinetics (PK) of a selection of compounds (36, 45, 47 , and 41 ) at $5 \mathrm{mg} / \mathrm{kg}$ administered both intravenous (iv) and orally (po) (Table 5). ${ }^{31}$ The resulting data showed moderate clearance for all compounds in both mouse (8.4$22.6 \mathrm{~mL} / \mathrm{min} / \mathrm{kg}$ ) and rat $(6.00-10.1 \mathrm{~mL} / \mathrm{min} / \mathrm{kg})$. All compounds with the exception of 41 showed high oral bioavailability in both species (63-92\%) with moderate volumes of distribution (Table 5). The plasma protein binding for all four of these compounds was high (>98\%), the lowest unsurprisingly shown by that presenting the lowest AlogP
(41). This corresponded to a higher blood clearance and shorter half-life $(0.66 \mathrm{~h})$ for 41 compared to $36(2.68 \mathrm{~h})$.

We thus decided to progress both 36 and 41 to a single dose pharmacokinetic/pharmacodynamic (PK/PD) experiment in DLD1 xenografts to investigate if the in vitro and PK profiles translated into sustained inhibition of MPS1 in vivo (Figure 6). We recently disclosed ${ }^{32}$ a xenograft model to assess modulation of MPS1 activity in vivo. Briefly, this model (Dox-DLD1) measures the level of MPS1 autophosphorylation in DLD1 cancer cells and, importantly, overcomes the issue of low MPS1 levels through doxycycline inducible expression of the kinase. We tested both compounds at $25 \mathrm{mg} / \mathrm{kg}$ and in addition compound 36 at $50 \mathrm{mg} / \mathrm{kg}$. The data are summarized in Figure 6. At $25 \mathrm{mg} / \mathrm{kg}$, both compounds led to a pronounced reduction of MPS1 autophosphorylation after 6 
h. Consistent with its longer half-life, only 36 showed significant inhibition at $24 \mathrm{~h}$. As expected, the $50 \mathrm{mg} / \mathrm{kg}$ dose of 36 resulted in an increased suppression of MPS1 autophosphorylation at 6 and $24 \mathrm{~h}$. The comparison of the plasma levels determined in the PK/PD study (Figure 6) after blood to plasma correction with the compound levels determined in the PK study described above and performed at lower doses (Table 5) was consistent with linear PK.

The robust modulation of the PD biomarkers observed for 36 prompted us to focus on this compound since a long duration of action is desirable for cell cycle targets. At $1 \mathrm{mg} / \mathrm{kg}$ iv and $5 \mathrm{mg} / \mathrm{kg}$ po, 36 showed complete bioavailability (100\%), low clearance $(1.2 \mathrm{~mL} / \mathrm{min} / \mathrm{kg})$, a moderate volume of distribution $(1.1 \mathrm{~L} / \mathrm{kg})$, and a $12 \mathrm{~h}$ half-life (Table 6) in a dog PK study.

Table 6. Dog Blood Pharmacokinetics not Dogblood 36 at 1 $\mathrm{mg} / \mathrm{kg}$ iv and $5 \mathrm{mg} / \mathrm{kg} \mathrm{po}^{a}$

\begin{tabular}{|c|c|c|c|c|c|c|c|c|}
\hline Compd & Structure & species & $\begin{array}{l}\mathbf{t}_{1 / 2} \\
\text { (h) }\end{array}$ & $\underset{(\mathrm{mL} / \mathrm{min} / \mathrm{kg})}{\mathrm{Cl}}$ & $\begin{array}{c}\mathrm{Cmax}_{\mathrm{po}} \\
(\mathrm{nmol} / \mathrm{L})\end{array}$ & $\underset{\left(h^{*} \mathrm{nmol} / \mathrm{L}\right)^{\mathrm{b}}}{\mathrm{AUC}_{\mathrm{po}}}$ & $\begin{array}{c}V_{\text {ss }} \\
(\mathbf{L} / \mathbf{k g})\end{array}$ & $\begin{array}{c}F \\
(\%)\end{array}$ \\
\hline 36 & & $\operatorname{dog}$ & 12 & 1.2 & 7770 & 147035 & 1.1 & 100 \\
\hline
\end{tabular}

${ }^{a_{\text {The }}}$ compound was administered as the dichloride salt in saline containing $10 \%$ DMSO. ${ }^{b} \mathrm{AUC}_{\text {last }} 48 \mathrm{~h}$.

We were intrigued by the high bioavailability of 36 , particularly given its poor solubility. Interestingly, $\mathrm{p} K_{\mathrm{a}}$ values for 36 were determined as 6.22 and 2.63. This suggests that, while the compound primarily exists as the free base at physiological $\mathrm{pH}$, it is protonated in the acidic environment of the stomach, likely accelerating the dissolution and enabling high bioavailability despite modest solubility at physiological $\mathrm{pH}$. This is an attractive feature of the pyrido $[3,4-$ d]pyrimidine scaffold since it avoids the well-recognized risk associated with drugs carrying a positive charge at physiological $\mathrm{pH}$, namely, hERG inhibition, efflux, and detrimental effects on passive permeation while still allowing high bioavailability and salt formation. To shed light on the question of which atom represents the weakly basic center, we performed a calculation using MoKa. ${ }^{33}$ This calculation predicted that the nitrogen atom of the pyridine ring is by far the most basic atom.

To complete the in vitro profiling, 36 was tested in a wide panel of more than 400 kinases (Supporting Information, Tables S5-S8). As we had seen with our previous MPS1 inhibitor $5,{ }^{17}$ only a small number of other kinases were inhibited by 36, in particular JNK1, JNK2, JNK3, and LRRK2 at $>80 \%$ at $1 \mu \mathrm{M}$. Follow up $\mathrm{IC}_{50}$ values were obtained (JNK1 $\mathrm{IC}_{50}=92 \mathrm{nM}$, JNK2 $\mathrm{IC}_{50}=76 \mathrm{nM}$, JNK3 $\mathrm{IC}_{50}=242 \mathrm{nM}$, and LRRK2 $\mathrm{IC}_{50}=48 \mathrm{nM}$ ) showing that 36 is selective for MPS1 over these other kinases. Furthermore, 36 also showed a clean CYP and hERG profile (Supporting Information, Tables S9 and S10).

Following extensive in vivo testing, particularly in combination with paclitaxel, the results of which will be published in due course (manuscript in preparation), we nominated 36 as our candidate. The synthesis of $\mathbf{3 6}$ has been scaled up into the kilogram range, and the drug is currently undergoing Phase 1 clinical trials.

\section{CONCLUSIONS}

We describe herein the discovery of our MPS1 inhibitor 36 (BOS172722). The starting point for the work described here was a series of previously reported pyrido $[3,4-d]$ pyrimidine inhibitors. These earlier compounds already showed promising in vitro potency and selectivity but suffered from a number of liabilities, particularly high lipophilicity and rapid metabolism in HLM. Optimizing HLM metabolism proved challenging since commonly used approaches, such as identification of metabolites and lowering lipophilicity, did not help. Key to overcoming this problem was the serendipitous finding that introduction of a methyl group at the 6-position of the pyrido $[3,4-d]$ pyrimidine core significantly improved HLM stability. Met ID studies suggested that the methyl group suppressed metabolism at the distant aniline portion of the molecule, likely by blocking the preferred pharmacophore through which $\mathrm{P} 450$ recognized the compound. Compound 17 is thus an interesting example where metabolism is not primarily driven by hydrophobicity or the presence of a particular metabolic hotspot but by recognition of a specific pharmacophore distant from the site of metabolism. These results underscore the importance of systematic chemical modification to solve high metabolic turnover.

Further optimization led to a set of compounds with promising in vitro profile, and we progressed a number of selected compounds to $\mathrm{PK}$ and subsequently $\mathrm{PK} / \mathrm{PD}$ experiments. Compound 36 emerged as our candidate showing excellent PK in mouse, rat, and dog. Data showing robust efficacy of 36 in combination with paclitaxel in in vivo models will be published shortly.

Interestingly, 36 showed very good bioavailability in all three species despite very modest solubility at physiological $\mathrm{pH}$. We attribute this observation to the weakly basic character of 36 $\left(\mathrm{p} K_{\mathrm{a}}=6.22\right)$ and other compounds in this series, which is likely accelerating their dissolution in the acidic environment of the stomach.

The synthesis of $\mathbf{3 6}$ has been scaled to the kilogram range, and the compound is currently in Phase 1 clinical trials.

\section{EXPERIMENTAL SECTION}

General Chemistry Information. Starting materials, reagents, and solvents for reactions were reagent grade and used as purchased. Chromatography solvents were HPLC grade and were used without further purification. Thin layer chromatography (TLC) analysis was performed using silica gel 60 F-254 thin layer plates. Flash column chromatography was carried out using columns prepacked with $40-$ $63 \mu \mathrm{m}$ silica. Microwave-assisted reactions were carried out using a Biotage Initiator microwave system. LCMS and HRMS analyses were performed on a HPLC system with diode array detector operating at $254 \mathrm{~nm}$, fitted with a reverse-phase $50 \times 4.6 \mathrm{~mm}$ column at a temperature of $22{ }^{\circ} \mathrm{C}$, connected to a time of flight (ToF) mass spectrometer (ESI). The following solvent system, at a flow rate of 2 $\mathrm{mL} / \mathrm{min}$, was used: solvent $\mathrm{A}$, methanol; solvent $\mathrm{B}, 0.1 \%$ formic acid in water. Gradient elution was as follows: 1:9 (A:B) to 9:1 (A:B) over $2.5 \mathrm{~min}, 9: 1$ (A:B) for $1 \mathrm{~min}$ then reversion back to $1: 9$ (A:B) over $0.3 \mathrm{~min}, 1: 9$ (A:B) for $0.2 \mathrm{~min} .{ }^{1} \mathrm{H}$ NMR spectra were recorded on a Bruker Avance $500 \mathrm{MHz}$ spectrometer using an internal deuterium lock. NMR data is given as follows: chemical shift $(\delta)$ in ppm, multiplicity, coupling constants $(J)$ given in $\mathrm{Hz}$, and integration. The purity of final compounds was determined by HPLC as described above and is $\geq 95 \%$ unless specified otherwise.

Compounds 8-chloro-2-(methylthio)pyrido[3,4-d]pyrimidine ${ }^{28} 7$, 2 -(methylthio)- $N$-neopentylpyrido $[3,4-d]$ pyrimidin-8-amine ${ }^{28} \mathbf{8}, \quad 2-$ (methylsulfonyl)- $N$-neopentylpyrido $[3,4-d]$ pyrimidin- 8 -amine ${ }^{28} 9,8$ chloro-2-(methylsulfonyl)pyrido[3,4-d] pyrimidine $^{28} \mathbf{1 8}, \mathrm{N}$-(2-me- 
thoxy-4-(1-methyl-1H-pyrazol-4-yl)phenyl)formamide ${ }^{28} 19$, 8-chloro$N$-(2-methoxy-4-(1-methyl-1H-pyrazol-4-yl)phenyl)pyrido[3,4-d]pyrimidin-2-amine ${ }^{28} 20, N^{2}$-(2-methoxy-4-(1-methyl-1H-pyrazol-4yl)phenyl)- $N^{8}$-neopentylpyrido[3,4- $\left.d\right]$ pyrimidine-2,8-diamine ${ }^{17,28} \mathbf{2 1}$, 8-chloro-6-methyl-2-(methythio)pyrido $[3,4-d]$ pyrimidine $^{28}$ 22, 6methyl-2-(methylthio)- $N$-neopentylpyrido $[3,4-d]$ pyrimidin-8-amine ${ }^{28}$ 23, and 6-methyl-2-(methylsulfonyl)- $N$-neopentylpyrido[3,4-d]pyrimidin-8-amine ${ }^{28} 26$ were synthesized by previously reported methods.

Preparation of Compounds in Scheme 1. General Procedure for NaH Mediated Displacement on 9 (Compounds 14-17). To a cooled $\left(0{ }^{\circ} \mathrm{C}\right)$ solution of appropriate formamide (1 equiv) in THF $(3 \mathrm{~mL})$ was added sodium hydride (60\% dispersion in oil, 1.6 equiv). The reaction mixture was stirred at r.t. for $10 \mathrm{~min}$. The reaction mixture was cooled to $0{ }^{\circ} \mathrm{C}$, and appropriate sulfone ( 1.2 equiv) was added. The reaction mixture was stirred for $18 \mathrm{~h}$, while slowly warming to r.t. aq $\mathrm{NaOH}(1 \mathrm{M}, 1 \mathrm{~mL})$ and $\mathrm{MeOH}(1 \mathrm{~mL})$ were added, and the reaction mixture was stirred at r.t. for $1 \mathrm{~h}$. The reaction mixture was concentrated in vacuo, and the residue was diluted with EtOAc and water. The aqueous layer was re-extracted with EtOAc and $\mathrm{CH}_{2} \mathrm{Cl}_{2}$. The combined organic layers were washed with water and brine, dried $\left(\mathrm{MgSO}_{4}\right)$, and concentrated in vacuo. The residue was purified by flash column chromatography $(0-10 \% \mathrm{MeOH}$ in EtOAc or $\mathrm{CH}_{2} \mathrm{Cl}_{2}$ ) and, if necessary, followed by SCX-2 cartridge $\left(\mathrm{MeOH}, 1 \mathrm{M} \mathrm{NH}_{3}\right.$ in $\left.\mathrm{MeOH}\right)$ to afford the title compounds.

$N^{2}$-(4-(1,3-Dimethyl-1H-pyrazol-4-yl)-2-methoxyphenyl)- $N^{8}$ neopentylpyrido[3,4-d]pyrimidine-2,8-diamine 14. Using $\mathrm{N}$-(4(1,3-dimethyl-1H-pyrazol-4-yl)-2-methoxyphenyl)formamide $\mathbf{1 0}$ and 2-(methylsulfonyl)- $N$-neopentylpyrido $[3,4-d]$ pyrimidin-8-amine $9 .{ }^{28}$ Yield $=21 \%$. HRMS $($ ESI $) \mathrm{m} / z$ calcd for $\mathrm{C}_{24} \mathrm{H}_{30} \mathrm{~N}_{7} \mathrm{O}(\mathrm{M}+\mathrm{H})$ 432.2506, found 432.2502; ${ }^{1} \mathrm{H}$ NMR $\left(500 \mathrm{MHz}, \mathrm{CD}_{3} \mathrm{OD}\right) \delta 9.07(\mathrm{~s}$, $1 \mathrm{H}), 8.42(\mathrm{~d}, J=8.0 \mathrm{~Hz}, 1 \mathrm{H}), 7.73(\mathrm{~s}, 1 \mathrm{H}), 7.71(\mathrm{~d}, J=6.0 \mathrm{~Hz}, 1 \mathrm{H})$, $7.10(\mathrm{~d}, J=1.5 \mathrm{~Hz}, 1 \mathrm{H}), 7.03(\mathrm{dd}, J=8.0,1.5 \mathrm{~Hz}, 1 \mathrm{H}), 6.85(\mathrm{~d}, J=$ $6.0 \mathrm{~Hz}, 1 \mathrm{H}), 4.00(\mathrm{~s}, 3 \mathrm{H}), 3.88(\mathrm{~s}, 3 \mathrm{H}), 3.40(\mathrm{~s}, 2 \mathrm{H}), 2.40(\mathrm{~s}, 3 \mathrm{H})$, $1.09(\mathrm{~s}, 9 \mathrm{H})$.

$N^{2}$-(4-(1,5-Dimethyl-1H-pyrazol-4-yl)-2-methoxyphenyl)- $N^{8}$. neopentylpyrido[3,4-d]pyrimidine-2,8-diamine 15 . Using $\mathrm{N}$-(4(1,5-dimethyl-1H-pyrazol-4-yl)-2-methoxyphenyl)formamide 11 and 2-(methylsulfonyl)- $N$-neopentylpyrido $[3,4-d]$ pyrimidin-8-amine $9 .{ }^{28}$ Yield $=8 \%$. HRMS $($ ESI $) \mathrm{m} / z$ calcd for $\mathrm{C}_{24} \mathrm{H}_{30} \mathrm{~N}_{7} \mathrm{O}(\mathrm{M}+\mathrm{H})$ 432.2506, found 432.2504; ${ }^{1} \mathrm{H} \mathrm{NMR}\left(500 \mathrm{MHz}, \mathrm{CDCl}_{3}\right) \delta 9.02(\mathrm{~s}$, $1 \mathrm{H}), 8.51(\mathrm{br} \mathrm{s}, 1 \mathrm{H}), 8.05(\mathrm{~m}, 1 \mathrm{H}), 7.84(\mathrm{~m}, 1 \mathrm{H}), 7.58(\mathrm{~s}, 1 \mathrm{H}), 6.99$ $(\mathrm{dd}, J=8.2,1.8 \mathrm{~Hz}, 1 \mathrm{H}), 6.96(\mathrm{~d}, J=1.8 \mathrm{~Hz}, 1 \mathrm{H}), 6.80(\mathrm{br} \mathrm{s}, 1 \mathrm{H})$, $3.99(\mathrm{~s}, 3 \mathrm{H}), 3.88(\mathrm{~s}, 3 \mathrm{H}), 3.64(\mathrm{br} \mathrm{s}, 2 \mathrm{H}), 2.42(\mathrm{~s}, 3 \mathrm{H}), 1.14(\mathrm{~s}, 9 \mathrm{H})$.

$N^{2}$-(4-(1,2-Dimethyl-1H-imidazol-5-yl)-2-methoxyphenyl)- $N^{8}$ neopentylpyrido[3,4-d]pyrimidine-2,8-diamine 16. Using $\mathrm{N}$-(4(1,2-dimethyl- $1 H$-imidazol-5-yl)-2-methoxyphenyl)formamide $\mathbf{1 2}$ and 2-(methylsulfonyl)- $N$-neopentylpyrido[3,4-d]pyrimidin-8-amine 9. ${ }^{28}$ Yield $=21 \%$. HRMS $($ ESI $) \mathrm{m} / z$ calcd for $\mathrm{C}_{24} \mathrm{H}_{30} \mathrm{~N}_{7} \mathrm{O}(\mathrm{M}+$ H) 432.2506, found 432.2504; ${ }^{1} \mathrm{H}$ NMR $\left(500 \mathrm{MHz}, \mathrm{CDCl}_{3}\right) \delta 9.04$ $(\mathrm{s}, 1 \mathrm{H}), 8.76(\mathrm{~d}, J=8.0 \mathrm{~Hz}, 1 \mathrm{H}), 8.12(\mathrm{~s}, 1 \mathrm{H}), 7.94(\mathrm{~d}, J=6.0 \mathrm{~Hz}$, $1 \mathrm{H}), 7.21(\mathrm{~s}, 1 \mathrm{H}), 6.99(\mathrm{dd}, J=8.0,2.0 \mathrm{~Hz}, 1 \mathrm{H}), 6.91(\mathrm{~d}, J=2.0 \mathrm{~Hz}$, $1 \mathrm{H}), 6.79(\mathrm{~d}, J=6.0 \mathrm{~Hz}, 1 \mathrm{H}), 6.58(\mathrm{br} \mathrm{s}, 1 \mathrm{H}), 4.02(\mathrm{~s}, 3 \mathrm{H}), 3.67(\mathrm{~s}$, $3 \mathrm{H}), 3.50(\mathrm{~d}, J=6.0 \mathrm{~Hz}, 2 \mathrm{H}), 2.82(\mathrm{~s}, 3 \mathrm{H}), 1.12(\mathrm{~s}, 9 \mathrm{H})$.

$N^{2}$-(2-Methoxy-4-(4-methyl-4H-1,2,4-triazol-3-yl)phenyl)- $N^{8}$. neopentylpyrido[3,4-d]pyrimidine-2,8-diamine 17. Using $\mathrm{N}$-(2methoxy-4-(4-methyl-4H-1,2,4-triazol-3-yl)phenyl)formamide 13 and 2-(methylsulfonyl)- $N$-neopentylpyrido[3,4- $d]$ pyrimidin-8-amine 9. ${ }^{28}$ Yield $=12 \%$. HRMS $($ ESI $) \mathrm{m} / z$ calcd for $\mathrm{C}_{22} \mathrm{H}_{27} \mathrm{~N}_{8} \mathrm{O}(\mathrm{M}+$ H) 419.2302 , found $419.2288 ;{ }^{1} \mathrm{H}$ NMR $\left(500 \mathrm{MHz}, \mathrm{CD}_{3} \mathrm{OD}\right) \delta 9.15$ $(\mathrm{s}, 1 \mathrm{H}), 8.74(\mathrm{~d}, J=8.5 \mathrm{~Hz}, 1 \mathrm{H}), 8.57(\mathrm{~s}, 1 \mathrm{H}), 7.77(\mathrm{~d}, J=6.0 \mathrm{~Hz}$, $1 \mathrm{H}), 7.43(\mathrm{~d}, J=1.5 \mathrm{~Hz}, 1 \mathrm{H}), 7.35(\mathrm{dd}, J=8.5,1.5 \mathrm{~Hz}, 1 \mathrm{H}), 6.90(\mathrm{~d}$, $J=6.0 \mathrm{~Hz}, 1 \mathrm{H}), 4.07(\mathrm{~s}, 3 \mathrm{H}), 3.87(\mathrm{~s}, 3 \mathrm{H}), 3.44(\mathrm{~s}, 2 \mathrm{H}), 1.10(\mathrm{~s}, 9 \mathrm{H})$.

Preparation of Compounds in Scheme 2. General Procedure for Amine Displacement on 22. To a solution of 8-chloro-6-methyl2 -(methythio)pyrido $[3,4-d]$ pyrimidine 22 (1 equiv) in NMP (20 $\mathrm{mL})$ was added appropriate amine ( 2 equiv) and triethylamine $(5$ equiv). The reaction mixture was heated to $100{ }^{\circ} \mathrm{C}$ for $36 \mathrm{~h}$. The reaction mixture was diluted with EtOAc and water, dried $\left(\mathrm{MgSO}_{4}\right)$, and concentrated in vacuo. The residue was purified by flash column chromatography (0-50\% EtOAc in cyclohexane) to afford the title compounds.

2-(6-Methyl-2-(methylthio)pyrido[3,4-d]pyrimidin-8-yl)-7-oxa-2azaspiro[3.5]nonane 24. Using 7-oxa-2-azaspiro[3.5]nonane. Yield = $40 \%$. HRMS (ESI) $m / z$ calcd for $\mathrm{C}_{16} \mathrm{H}_{21} \mathrm{~N}_{4} \mathrm{OS}(\mathrm{M}+\mathrm{H}) 317.1431$, found 317.1422; ${ }^{1} \mathrm{H}$ NMR (500 MHz, $\left.\mathrm{CD}_{3} \mathrm{OD}\right) \delta 9.00(\mathrm{~s}, 1 \mathrm{H}), 6.76$ (app s, $1 \mathrm{H}), 4.33($ br s, $4 \mathrm{H}), 3.71($ app t, $J=5.0 \mathrm{~Hz}, 4 \mathrm{H}), 2.65$ (s, $3 \mathrm{H}), 2.44(\mathrm{~d}, J=0.5 \mathrm{~Hz}, 3 \mathrm{H}), 1.90($ app t, $J=5.0 \mathrm{~Hz}, 4 \mathrm{H})$.

3-Methyl-1-(6-methyl-2-(methylthio)pyrido[3,4-d]pyrimidin-8yl)azetidine-3-carbonitrile 25. Using 3-methylazetidine-3-carbonitrile hydrochloride. Yield $=66 \%$. HRMS $(\mathrm{ESI}) \mathrm{m} / z$ calcd for $\mathrm{C}_{14} \mathrm{H}_{16} \mathrm{~N}_{5} \mathrm{~S}(\mathrm{M}+\mathrm{H}) 268.1121$, found $268.1119 ;{ }^{1} \mathrm{H}$ NMR $(500 \mathrm{MHz}$, $\left.\mathrm{CD}_{3} \mathrm{OD}\right) \delta 9.05(\mathrm{~s}, 1 \mathrm{H}), 6.89(\mathrm{app} \mathrm{s}, 1 \mathrm{H}), 4.83$ (br d, $J=7.5 \mathrm{~Hz}$, $2 \mathrm{H}), 4.48(\mathrm{br} \mathrm{d}, J=7.5 \mathrm{~Hz}, 2 \mathrm{H}), 2.64(\mathrm{~s}, 3 \mathrm{H}), 2.47(\mathrm{~d}, J=0.5 \mathrm{~Hz}$, $3 \mathrm{H}), 1.78$ (s, 3H).

General Procedure for $m-C P B A$ Oxidation on 23-25. To a cooled $\left(0{ }^{\circ} \mathrm{C}\right)$ solution of appropriate sulfide ( 1 equiv) in $\mathrm{CH}_{2} \mathrm{Cl}_{2}(10$ $\mathrm{mL}$ ) was added $m$-CPBA ( 3 equiv). The reaction mixture was stirred for $18 \mathrm{~h}$, while slowly warming to r.t. In some instances, further $m$ CPBA was needed to achieve full conversion. The reaction mixture was quenched with water and extracted with $\mathrm{CH}_{2} \mathrm{Cl}_{2}$. The combined organic layers were washed with aq. sat. $\mathrm{NaHCO}_{3}$, dried $\left(\mathrm{MgSO}_{4}\right)$, and concentrated in vacuo. The residue was purified by flash column chromatography $\left(0-10 \% \mathrm{MeOH}\right.$ in $\left.\mathrm{CH}_{2} \mathrm{Cl}_{2}\right)$.

2-(6-Methyl-2-(methylsulfonyl)pyrido[3,4-d]pyrimidin-8-yl)-7oxa-2-azaspiro[3.5]nonane 27. Using 2-(6-methyl-2-(methylthio)pyrido[3,4- $d$ ] pyrimidin-8-yl)-7-oxa-2-azaspiro[3.5] nonane 24. Yield = $28 \%$. HRMS (ESI) $m / z$ calcd for $\mathrm{C}_{16} \mathrm{H}_{21} \mathrm{~N}_{4} \mathrm{O}_{3} \mathrm{~S}(\mathrm{M}+\mathrm{H}) 349.1329$, found $349.1318 ;{ }^{1} \mathrm{H}$ NMR (500 MHz, $\left.\mathrm{CD}_{3} \mathrm{OD}\right) \delta 9.38(\mathrm{~s}, 1 \mathrm{H}), 6.94$ (s, 1H), 4.29 (br s, 4H), $3.73($ app t, $J=5.5 \mathrm{~Hz}, 4 \mathrm{H}), 3.43(\mathrm{~s}, 3 \mathrm{H})$, $2.53(\mathrm{~s}, 3 \mathrm{H}), 1.92($ app t, $J=5.5 \mathrm{~Hz}, 4 \mathrm{H})$.

3-Methyl-1-(6-methyl-2-(methylsulfonyl)pyrido[3,4-d]pyrimidin8-yl)azetidine-3-carbonitrile 28. Using 3-methyl-1-(6-methyl-2(methylthio)pyrido[3,4-d] pyrimidin-8-yl)azetidine-3-carbonitrile 25 . Yield $=77 \%$. HRMS (ESI) $m / z$ calcd for $\mathrm{C}_{14} \mathrm{H}_{16} \mathrm{~N}_{5} \mathrm{O}_{2} \mathrm{~S}(\mathrm{M}+\mathrm{H})$ 318.1019, found 318.1009; ${ }^{1} \mathrm{H}$ NMR (500 MHz, $\left.\mathrm{CD}_{3} \mathrm{OD}\right) \delta 9.46(\mathrm{~s}$, $1 \mathrm{H}), 7.08(\mathrm{~s}, 1 \mathrm{H}), 4.54(\mathrm{br} \mathrm{s}, 4 \mathrm{H}), 3.44(\mathrm{~s}, 3 \mathrm{H}), 2.56(\mathrm{~s}, 3 \mathrm{H}), 1.80$ (s, $3 \mathrm{H})$.

$N^{2}$-(4-(1,2-Dimethyl-1H-imidazol-5-yl)-2-methoxyphenyl)-6methyl- $N^{8}$-neopentylpyrido[3,4-d]pyrimidine-2,8-diamine 34. To a cooled $\left(0{ }^{\circ} \mathrm{C}\right)$ solution of $\mathrm{N}$-(4-(1,2-dimethyl- $1 \mathrm{H}$-imidazol-5-yl)-2methoxyphenyl)formamide 12 (17 mg, $0.069 \mathrm{mmol})$ in THF $(3 \mathrm{~mL})$ was added sodium hydride $(2.7 \mathrm{mg}, 0.11 \mathrm{mmol}, 60 \%$ dispersion in oil). The reaction mixture was stirred at r.t. for $10 \mathrm{~min}$. The reaction mixture was cooled to $0{ }^{\circ} \mathrm{C}$, and 6-methyl-2-(methylsulfonyl)- $\mathrm{N}$ neopentylpyrido[3,4- $d]$ pyrimidin- 8 -amine $\quad \mathbf{2 6}^{28}(25.6 \mathrm{mg}, \quad 0.083$ mmol) was added. The reaction mixture was stirred for $18 \mathrm{~h}$, while slowly warming to r.t. aq $\mathrm{NaOH}(1 \mathrm{M}, 1 \mathrm{~mL})$ and $\mathrm{MeOH}(1 \mathrm{~mL})$ were added, and the reaction mixture was stirred at r.t. for $1 \mathrm{~h}$. The reaction mixture was concentrated in vacuo, and the residue diluted with EtOAc and water. The aqueous layer was re-extracted with EtOAc and $\mathrm{CH}_{2} \mathrm{Cl}_{2}$. The combined organic layers were washed with water and brine, dried $\left(\mathrm{MgSO}_{4}\right)$, and concentrated in vacuo. The residue was purified by flash column chromatography $(0-10 \%$ $\mathrm{MeOH}$ in EtOAc) and followed by SCX-2 cartridge $(\mathrm{MeOH}, 1 \mathrm{M}$ $\mathrm{NH}_{3}$ in $\mathrm{MeOH}$ ) to afford the title compound (3.3 mg, 11\%). HRMS (ESI) $\mathrm{m} / z$ calcd for $\mathrm{C}_{25} \mathrm{H}_{32} \mathrm{~N}_{7} \mathrm{O}(\mathrm{M}+\mathrm{H}) 446.2663$, found 446.2648 ; ${ }^{1} \mathrm{H}$ NMR $\left(500 \mathrm{MHz}, \mathrm{CD}_{3} \mathrm{OD}\right) \delta 9.02(\mathrm{~s}, 1 \mathrm{H}), 8.57(\mathrm{~d}, J=8.5 \mathrm{~Hz}$, $1 \mathrm{H}), 7.09(\mathrm{~d}, J=2.0 \mathrm{~Hz}, 1 \mathrm{H}), 7.02(\mathrm{dd}, J=8.5,2.0 \mathrm{~Hz}, 1 \mathrm{H}), 6.88(\mathrm{~s}$, $1 \mathrm{H}), 6.70(\mathrm{~d}, J=1.0 \mathrm{~Hz}, 1 \mathrm{H}), 4.02(\mathrm{~s}, 3 \mathrm{H}), 3.61(\mathrm{~s}, 3 \mathrm{H}), 3.45(\mathrm{~s}$, $2 \mathrm{H}), 2.45(\mathrm{~s}, 3 \mathrm{H}), 2.44(\mathrm{~d}, J=1.0 \mathrm{~Hz}, 3 \mathrm{H}), 1.09(\mathrm{~s}, 9 \mathrm{H})$.

General Procedure for Cesium Carbonate Mediated Substitution on 26,27 , or 28 . To a solution of the appropriate sulfone (1 equiv) in DMSO (20 mg sulfone $/ \mathrm{mL}$ ) was added appropriate formamide (1.2 equiv) and cesium carbonate ( 2 equiv). The reaction mixture was heated to $120^{\circ} \mathrm{C}$ in a closed cap vial for $18 \mathrm{~h}$. The reaction mixture was diluted with EtOAc and water. The aqueous layer was reextracted with EtOAc, and the combined organic layers were dried $\left(\mathrm{MgSO}_{4}\right)$ and concentrated in vacuo. The residue was purified by flash column chromatography $\left(0-10 \% \mathrm{MeOH}\right.$ in $\left.\mathrm{CH}_{2} \mathrm{Cl}_{2}\right)$ and if necessary 
followed by SCX-2 cartridge ( $\mathrm{MeOH}, 1 \mathrm{M} \mathrm{NH}_{3}$ in $\left.\mathrm{MeOH}\right)$ to afford the title compounds.

$N^{2}$-(2-Methoxy-4-(4-methyl-4H-1,2,4-triazol-3-yl)phenyl)-6methyl- $N^{8}$-neopentylpyrido[3,4-d]pyrimidine-2,8-diamine 35 . Using 6-methyl-2-(methylsulfonyl)- $N$-neopentylpyrido[3,4-d]pyrimidin-8-amine 26 and $N$-(2-methoxy-4-(4-methyl-4H-1,2,4-triazol-3-yl)phenyl)formamide 13. Yield $=48 \%$. HRMS (ESI) $\mathrm{m} / z$ calcd for $\mathrm{C}_{23} \mathrm{H}_{29} \mathrm{~N}_{8} \mathrm{O}(\mathrm{M}+\mathrm{H})$ 433.2459, found 433.2447; ${ }^{1} \mathrm{H}$ NMR (500 $\left.\mathrm{MHz}, \mathrm{CD}_{3} \mathrm{OD}\right) \delta 9.05(\mathrm{~s}, 1 \mathrm{H}), 8.75(\mathrm{~d}, J=8.5 \mathrm{~Hz}, 1 \mathrm{H}), 8.56(\mathrm{~s}, 1 \mathrm{H})$, $7.42(\mathrm{~d}, J=2.0 \mathrm{~Hz}, 1 \mathrm{H}), 7.34(\mathrm{dd}, J=8.5,2.0 \mathrm{~Hz}, 1 \mathrm{H}), 6.71(\mathrm{~d}, J=$ $1.0 \mathrm{~Hz}, 1 \mathrm{H}), 4.07(\mathrm{~s}, 3 \mathrm{H}), 3.87(\mathrm{~s}, 3 \mathrm{H}), 3.48(\mathrm{~s}, 2 \mathrm{H}), 2.44$ (app s, $3 \mathrm{H}), 1.10(\mathrm{~s}, 9 \mathrm{H})$.

$N^{2}$-(2-Ethoxy-4-(4-methyl-4H-1,2,4-triazol-3-yl)phenyl)-6-methyl- $N^{8}$-neopentylpyrido[3,4-d]pyrimidine-2,8-diamine 36. Using 6methyl-2-(methylsulfonyl)- $N$-neopentylpyrido[3,4-d]pyrimidin-8amine 26 and $\mathrm{N}$-(2-ethoxy-4-(4-methyl-4H-1,2,4-triazol-3-yl)phenyl)formamide 29. Yield $=70 \%$. HRMS (ESI) $m / z$ calcd for $\mathrm{C}_{24} \mathrm{H}_{31} \mathrm{~N}_{8} \mathrm{O}$ $(\mathrm{M}+\mathrm{H})$ 447.2615, found 447.2629; ${ }^{1} \mathrm{H}$ NMR $(500 \mathrm{MHz}$, acetone$\left.d_{6}\right) \delta 9.11(\mathrm{~s}, 1 \mathrm{H}), 8.80(\mathrm{~d}, J=8.5 \mathrm{~Hz}, 1 \mathrm{H}), 8.37(\mathrm{~s}, 1 \mathrm{H}), 8.21(\mathrm{br} \mathrm{s}$, $1 \mathrm{H}), 7.46(\mathrm{~d}, J=2.0 \mathrm{~Hz}, 1 \mathrm{H}), 7.40(\mathrm{dd}, J=8.5,2.0 \mathrm{~Hz}, 1 \mathrm{H}), 6.74(\mathrm{~d}$, $J=0.5 \mathrm{~Hz}, 1 \mathrm{H}), 4.35(\mathrm{q}, J=7.0 \mathrm{~Hz}, 2 \mathrm{H}), 3.90(\mathrm{~s}, 3 \mathrm{H}), 3.51(\mathrm{~s}, 2 \mathrm{H})$, $2.41(\mathrm{~d}, J=0.5 \mathrm{~Hz}, 3 \mathrm{H}), 1.55(\mathrm{t}, J=7.0 \mathrm{~Hz}, 3 \mathrm{H}), 1.08(\mathrm{~s}, 9 \mathrm{H})$.

$N^{2}$-(4-(4,5-Dimethyl-4H-1,2,4-triazol-3-yl)-2-ethoxyphenyl)-6methyl- $N^{8}$-neopentylpyrido[3,4-d]pyrimidine-2,8-diamine 37 . Using 6-methyl-2-(methylsulfonyl)- $N$-neopentylpyrido[3,4-d]pyrimidin-8-amine $26^{28}$ and $N$-(2-ethoxy-4-(4,5-dimethyl-4H-1,2,4triazol-3-yl)phenyl)formamide 30 . Yield $=56 \%$ HRMS (ESI) $\mathrm{m} / \mathrm{z}$ calcd for $\mathrm{C}_{25} \mathrm{H}_{33} \mathrm{~N}_{8} \mathrm{O}(\mathrm{M}+\mathrm{H})$ 461.2772, found 461.2756; ${ }^{1} \mathrm{H}$ NMR $\left(500 \mathrm{MHz}, \mathrm{CD}_{3} \mathrm{OD}\right) \delta 9.06(\mathrm{~s}, 1 \mathrm{H}), 8.75(\mathrm{~d}, J=8.5 \mathrm{~Hz}, 1 \mathrm{H}), 7.34(\mathrm{~d}$, $J=1.9 \mathrm{~Hz}, 1 \mathrm{H}), 7.28(\mathrm{dd}, J=8.5,1.9 \mathrm{~Hz}, 1 \mathrm{H}), 6.72(\mathrm{~s}, 1 \mathrm{H}), 4.30(\mathrm{q}, J$ $=7.2 \mathrm{~Hz}, 2 \mathrm{H}), 3.71(\mathrm{~s}, 3 \mathrm{H}), 3.48(\mathrm{~s}, 2 \mathrm{H}), 2.53(\mathrm{~s}, 3 \mathrm{H}), 2.45(\mathrm{~s}, 3 \mathrm{H})$, $1.56(\mathrm{t}, J=7.2 \mathrm{~Hz}, 3 \mathrm{H}), 1.10(\mathrm{~s}, 9 \mathrm{H})$.

$N^{2}$-(4-(6,7-Dihydro-5H-pyrrolo[2, 1-c][1,2,4]triazol-3-yl)-2-methoxyphenyl)-6-methyl- $N^{8}$-neopentylpyrido[3,4-d]pyrimidine-2,8diamine 38. Using 6-methyl-2-(methylsulfonyl)- $N$-neopentylpyrido$[3,4-d]$ pyrimidin-8-amine $26^{28}$ and $N$-(4-(6,7-dihydro- $5 H$-pyrrolo$[2,1-c][1,2,4]$ triazol-3-yl)-2-methoxyphenyl)formamide 31. Purified by $\mathrm{SCX}-2$ cartridge $\left(\mathrm{MeOH}, 1 \mathrm{M} \mathrm{NH}_{3}\right.$ in $\left.\mathrm{MeOH}\right)$ followed by purification by HPLC. Yield $=31 \%$. HRMS (ESI) $\mathrm{m} / z$ calcd for $\mathrm{C}_{25} \mathrm{H}_{31} \mathrm{~N}_{8} \mathrm{O}(\mathrm{M}+\mathrm{H})$ 459.2615, found 459.2571; ${ }^{1} \mathrm{H}$ NMR (500 $\left.\mathrm{MHz}, \mathrm{CDCl}_{3}\right) \delta 8.92(\mathrm{~s}, 1 \mathrm{H}), 8.71(\mathrm{~d}, J=8.3 \mathrm{~Hz}, 1 \mathrm{H}), 8.07(\mathrm{~s}, 1 \mathrm{H})$, $7.66(\mathrm{~d}, J=1.9 \mathrm{~Hz}, 1 \mathrm{H}), 7.26($ br d, $J=1.9 \mathrm{~Hz}, 1 \mathrm{H}), 6.59(\mathrm{~d}, J=0.9$ $\mathrm{Hz}, 1 \mathrm{H}), 6.53(\mathrm{br} \mathrm{t}, J=5.9 \mathrm{~Hz}, 1 \mathrm{H}), 4.24(\mathrm{t}, J=6.9 \mathrm{~Hz}, 2 \mathrm{H}), 4.04(\mathrm{~s}$, $3 \mathrm{H}), 3.49(\mathrm{~d}, J=5.9 \mathrm{~Hz}, 2 \mathrm{H}), 3.06(\mathrm{dd}, J=8.3,6.9 \mathrm{~Hz}, 2 \mathrm{H}), 2.95-$ $2.80(\mathrm{~m}, 2 \mathrm{H}), 2.48(\mathrm{~d}, J=0.9 \mathrm{~Hz}, 3 \mathrm{H}), 1.11(\mathrm{~s}, 9 \mathrm{H})$.

$N^{2}-(4-(6,7-D i h y d r o-5 H-p y r r o l o[2,1-c][1,2,4]$ triazol-3-yl)-2-ethoxyphenyl)-6-methyl- $N^{8}$-neopentylpyrido[3,4-d]pyrimidine-2,8-diamine 39. Using 6-methyl-2-(methylsulfonyl)- $N$-neopentylpyrido[3,4d]pyrimidin-8-amine $26^{28}$ and $\mathrm{N}$-(4-(6,7-dihydro-5H-pyrrolo[2,1c] $[1,2,4]$ triazol-3-yl)-2-ethoxyphenyl)formamide 32 . Yield $=35 \%$. HRMS (ESI) $m / z$ calcd for $\mathrm{C}_{26} \mathrm{H}_{33} \mathrm{~N}_{8} \mathrm{O}(\mathrm{M}+\mathrm{H})$ 473.2777, found 473.2769; ${ }^{1} \mathrm{H}$ NMR $\left(500 \mathrm{MHz}, \mathrm{CD}_{3} \mathrm{OD}\right) \delta 9.00(\mathrm{~s}, 1 \mathrm{H}), 8.67(\mathrm{~d}, J=$ $8.5 \mathrm{~Hz}, 1 \mathrm{H}), 7.51(\mathrm{~d}, J=1.8 \mathrm{~Hz}, 1 \mathrm{H}), 7.39(\mathrm{dd}, J=8.5,1.8 \mathrm{~Hz}, 1 \mathrm{H})$, $6.67(\mathrm{~s}, 1 \mathrm{H}), 4.35-4.28(\mathrm{~m}, 4 \mathrm{H}), 3.47(\mathrm{~s}, 2 \mathrm{H}), 3.04-3.01(\mathrm{~m}, 2 \mathrm{H})$, $2.91-2.87(\mathrm{~m}, 2 \mathrm{H}), 2.43(\mathrm{~s}, 3 \mathrm{H}), 1.57(\mathrm{t}, J=6.9 \mathrm{~Hz}, 3 \mathrm{H}), 1.10(\mathrm{~s}$, $9 \mathrm{H})$.

$N^{2}$-(4-(5-(2-(Dimethylamino)ethyl)-4-methyl-4H-1,2,4-triazol-3yl)-2-ethoxyphenyl)-6-methyl- $N^{8}$-neopentylpyrido $[3,4-d]$ pyrimidine-2,8-diamine 40. Using 6-methyl-2-(methylsulfonyl)- $N$ neopentylpyrido[3,4-d]pyrimidin- 8 -amine $26^{28}$ and $\mathrm{N}$-(4-(5-(2(dimethylamino) ethyl)-4-methyl-4H-1,2,4-triazol-3-yl)-2ethoxyphenyl)formamide 33. Purified by reverse phase flash column chromatography $(0-100 \%$ water in $\mathrm{MeOH}$, followed by $0-30 \% 2 \mathrm{M}$ methanolic ammonia in $\mathrm{CH}_{2} \mathrm{Cl}_{2}$ ). Yield $=18 \%$. HRMS (ESI) $\mathrm{m} / z$ calcd for $\mathrm{C}_{28} \mathrm{H}_{40} \mathrm{~N}_{9} \mathrm{O}(\mathrm{M}+\mathrm{H})$ 518.3356, found 518.3370; ${ }^{1} \mathrm{H}$ NMR $\left(500 \mathrm{MHz}, \mathrm{CD}_{3} \mathrm{OD}\right) \delta 9.05(\mathrm{~s}, 1 \mathrm{H}), 8.75(\mathrm{~d}, J=8.5 \mathrm{~Hz}, 1 \mathrm{H}), 7.34(\mathrm{~d}$, $J=1.8 \mathrm{~Hz}, 1 \mathrm{H}), 7.28(\mathrm{dd}, J=8.5,1.8 \mathrm{~Hz}, 1 \mathrm{H}), 6.71(\mathrm{~s}, 1 \mathrm{H}), 4.30(\mathrm{q}, J$ $=7.0 \mathrm{~Hz}, 2 \mathrm{H}), 3.73(\mathrm{~s}, 3 \mathrm{H}), 3.47(\mathrm{~s}, 2 \mathrm{H}), 3.09(\mathrm{app} \mathrm{t}, J=7.5 \mathrm{~Hz}$, $2 \mathrm{H}), 2.91($ app t, $J=7.5 \mathrm{~Hz}, 2 \mathrm{H}), 2.44(\mathrm{~s}, 3 \mathrm{H}), 2.42(\mathrm{~s}, 6 \mathrm{H}), 1.56(\mathrm{t}, J$ $=7.0 \mathrm{~Hz}, 3 \mathrm{H}), 1.09(\mathrm{~s}, 9 \mathrm{H})$.
$\mathrm{N}$-(2-Ethoxy-4-(4-methyl-4H-1,2,4-triazol-3-yl)phenyl)-6-methyl8-(7-oxa-2-azaspiro[3.5]nonan-2-yl)pyrido[3,4-d]pyrimidin-2amine 41. Using 2-(6-methyl-2-(methylsulfonyl)pyrido[3,4-d]pyrimidin-8-yl)-7-oxa-2-azaspiro[3.5] nonane 27 and $N$-(2-ethoxy-4(4-methyl-4H-1,2,4-triazol-3-yl)phenyl)formamide 29 . Yield $=46 \%$. HRMS (ESI) $m / z$ calcd for $\mathrm{C}_{26} \mathrm{H}_{31} \mathrm{~N}_{8} \mathrm{O}_{2}(\mathrm{M}+\mathrm{H}) 487.2564$, found 487.2511; ${ }^{1} \mathrm{H}$ NMR $\left(500 \mathrm{MHz}, \mathrm{CD}_{3} \mathrm{OD}\right) \delta 9.06(\mathrm{~s}, 1 \mathrm{H}), 8.57(\mathrm{~d}, J=$ $8.5 \mathrm{~Hz}, 1 \mathrm{H}), 8.56(\mathrm{~s}, 1 \mathrm{H}), 7.39(\mathrm{~d}, J=2.0 \mathrm{~Hz}, 1 \mathrm{H}), 7.36(\mathrm{dd}, J=8.5$, $2.0 \mathrm{~Hz}, 1 \mathrm{H}), 6.78(\mathrm{~s}, 1 \mathrm{H}), 4.31-4.27(\mathrm{~m}, 6 \mathrm{H}), 3.87(\mathrm{~s}, 3 \mathrm{H}), 3.69$ (app t, $J=5.5 \mathrm{~Hz}, 4 \mathrm{H}), 2.44(\mathrm{~s}, 3 \mathrm{H}), 1.89($ app t, $J=5.5 \mathrm{~Hz}, 4 \mathrm{H})$, $1.54(\mathrm{t}, J=7.0 \mathrm{~Hz}, 3 \mathrm{H})$.

1-(2-((2-Ethoxy-4-(4-methyl-4H-1,2,4-triazol-3-yl)phenyl)amino)-6-methylpyrido[3,4-d]pyrimidin-8-yl)-3-methylazetidine-3carbonitrile 42. Using 3-methyl-1-(6-methyl-2-(methylsulfonyl)pyrido[3,4- $d]$ pyrimidin-8-yl)azetidine-3-carbonitrile 28 and $N$-(2ethoxy-4-(4-methyl-4H-1,2,4-triazol-3-yl)phenyl)formamide 29. Yield $=38 \%$. HRMS (ESI) $\mathrm{m} / z$ calcd for $\mathrm{C}_{24} \mathrm{H}_{26} \mathrm{~N}_{9} \mathrm{O}(\mathrm{M}+\mathrm{H})$ 456.2255, found 456.2180; ${ }^{1} \mathrm{H}$ NMR $\left(500 \mathrm{MHz}, \mathrm{CD}_{3} \mathrm{OD}\right) \delta 9.10(\mathrm{~s}$, $1 \mathrm{H}), 8.56(\mathrm{~s}, 1 \mathrm{H}), 8.46(\mathrm{~d}, J=8.5 \mathrm{~Hz}, 1 \mathrm{H}), 7.40(\mathrm{dd}, J=8.5,2.0 \mathrm{~Hz}$, $1 \mathrm{H}), 7.39(\mathrm{~d}, J=2.0 \mathrm{~Hz}, 1 \mathrm{H}), 6.91(\mathrm{~s}, 1 \mathrm{H}), 4.75(\mathrm{~d}, J=9.0 \mathrm{~Hz}, 2 \mathrm{H})$, 4.39 (d, $J=9.0 \mathrm{~Hz}, 2 \mathrm{H}), 4.28(\mathrm{q}, J=7.0 \mathrm{~Hz}, 2 \mathrm{H}), 3.88(\mathrm{~s}, 3 \mathrm{H}), 2.47$ $(\mathrm{s}, 3 \mathrm{H}), 1.75(\mathrm{~s}, 3 \mathrm{H}), 1.53(\mathrm{t}, J=7.0 \mathrm{~Hz}, 3 \mathrm{H})$.

Preparation of Compounds in Scheme 3. 8-Chloro-6-methyl2-(methylsulfonyl)pyrido[3,4-d]pyrimidine 43. A suspension of 8chloro-6-methyl-2-(methylthio)pyrido[3,4-d]pyrimidine 22 (1.13 g, $5.01 \mathrm{mmol})$ in $\mathrm{CH}_{2} \mathrm{Cl}_{2}(50 \mathrm{~mL})$ was treated with $m-\mathrm{CPBA}(77 \% \mathrm{w} /$ $\mathrm{w}, 2.60 \mathrm{~g}, 11.57 \mathrm{mmol}$ ) at $0{ }^{\circ} \mathrm{C}$. The reaction mixture was stirred for $18 \mathrm{~h}$, while slowly warming to r.t. The reaction was quenched with water and extracted with $\mathrm{CH}_{2} \mathrm{Cl}_{2}$. The combined organic layers were washed with aq. sat. $\mathrm{NaHCO}_{3}$, dried $\left(\mathrm{MgSO}_{4}\right)$, and concentrated in vacuo. The residue was purified by flash column chromatography (0$70 \%$ EtOAc in cyclohexane) to afford the title compound (972 mg, $75 \%$ ). HRMS (ESI) $m / z$ calcd for $\mathrm{C}_{9} \mathrm{H}_{9} \mathrm{ClN}_{3} \mathrm{O}_{2} \mathrm{~S}(\mathrm{M}+\mathrm{H}) 258.0099$, found 258.0092; ${ }^{1} \mathrm{H}$ NMR $\left(500 \mathrm{MHz}, \mathrm{CD}_{3} \mathrm{OD}\right) \delta 9.82(\mathrm{~s}, 1 \mathrm{H}), 7.96$ $(\mathrm{d}, J=0.5 \mathrm{~Hz}, 1 \mathrm{H}), 3.54(\mathrm{~s}, 3 \mathrm{H}), 2.78(\mathrm{~d}, J=0.5 \mathrm{~Hz}, 3 \mathrm{H})$.

8-Chloro-N-(2-ethoxy-4-(4-methyl-4H-1,2,4-triazol-3-yl)phenyl)6-methylpyrido[3,4-d]pyrimidin-2-amine 44. To a solution of $\mathrm{N}$-(2ethoxy-4-(4-methyl-4H-1,2,4-triazol-3-yl)phenyl)formamide 29 (1.88 g, $7.63 \mathrm{mmol})$ in THF $(70 \mathrm{~mL})$ was added $\mathrm{NaH}(60 \% \mathrm{w} / \mathrm{w}, 500 \mathrm{mg}$, $12.50 \mathrm{mmol}$ ) at $0{ }^{\circ} \mathrm{C}$. The reaction mixture was stirred at r.t. for 30 min. The mixture was cooled to $0{ }^{\circ} \mathrm{C}$, and 8-chloro-6-methyl-2(methylsulfonyl)pyrido[3,4- $d$ ] pyrimidine $43(2.50 \mathrm{~g}, 9.70 \mathrm{mmol})$ was added. The reaction mixture was stirred for $18 \mathrm{~h}$, while slowly warming to r.t. aq. $\mathrm{NaOH}(2 \mathrm{M}, 25 \mathrm{~mL})$ and $\mathrm{MeOH}(25 \mathrm{~mL})$ were added, and the resulting mixture stirred at r.t. for $1 \mathrm{~h}$. The reaction mixture was concentrated in vacuo, and the residue was diluted with $\mathrm{CH}_{2} \mathrm{Cl}_{2}$ and water. The aqueous layer was extracted with $\mathrm{CH}_{2} \mathrm{Cl}_{2}$, and the combined organic layers were dried $\left(\mathrm{MgSO}_{4}\right)$ and concentrated in vacuo. The residue was purified by flash column chromatography (0$6 \% \mathrm{MeOH}$ in $\mathrm{CH}_{2} \mathrm{Cl}_{2}$ ) to afford the title compound (3.24 g, quant). HRMS (ESI) $m / z$ calcd for $\mathrm{C}_{19} \mathrm{H}_{19} \mathrm{ClN}_{7} \mathrm{O}(\mathrm{M}+\mathrm{H}) 396.1339$, found 396.1335; ${ }^{1} \mathrm{H}$ NMR $\left(500 \mathrm{MHz},\left(\mathrm{CD}_{3}\right)_{2} \mathrm{SO}\right) \delta 9.46(\mathrm{~s}, 1 \mathrm{H}), 8.85(\mathrm{~d}, J$ $=8.3 \mathrm{~Hz}, 1 \mathrm{H}), 8.79(\mathrm{~s}, 1 \mathrm{H}), 8.56(\mathrm{~s}, 1 \mathrm{H}), 7.74(\mathrm{~d}, J=1.0 \mathrm{~Hz}, 1 \mathrm{H})$, $7.49-7.36(\mathrm{~m}, 2 \mathrm{H}), 4.25(\mathrm{q}, J=7.0 \mathrm{~Hz}, 2 \mathrm{H}), 3.80(\mathrm{~s}, 3 \mathrm{H}), 2.58(\mathrm{~s}$, $3 \mathrm{H}), 1.43(\mathrm{t}, J=7.0 \mathrm{~Hz}, 3 \mathrm{H})$.

General Procedure for Amine Displacement on 44 (Compounds $45-48)$. To a solution of the appropriate chloro compound (1 equiv) in NMP $(3 \mathrm{~mL})$ was added the appropriate amine or salt thereof (25 equiv) and triethylamine ( 5 equiv). The reaction mixture was heated to $100{ }^{\circ} \mathrm{C}$ in a closed cap vial for $18 \mathrm{~h}$. The reaction mixture was diluted with EtOAc and water. The organic layer was washed with brine, dried $\left(\mathrm{MgSO}_{4}\right)$, and concentrated in vacuo. The residue was purified by flash column chromatography (eluting with the appropriate solvent system) and, if necessary, followed by SCX-2 cartridge $\left(\mathrm{MeOH}, 1 \mathrm{M} \mathrm{NH}_{3}\right.$ in $\left.\mathrm{MeOH}\right)$.

(S)- $N^{8}$-(3,3-Dimethylbutan-2-yl)- $N^{2}$-(2-ethoxy-4-(4-methyl-4H1,2,4-triazol-3-yl)phenyl)-6-methylpyrido[3,4-d]pyrimidine-2,8-diamine 45. Using 8-chloro- $\mathrm{N}$-(2-ethoxy-4-(4-methyl-4H-1,2,4-triazol-3yl)phenyl)-6-methylpyrido[3,4- $d]$ pyrimidin-2-amine 44 and (S)-3,3dimethylbutan-2-amine at $130{ }^{\circ} \mathrm{C}$ for 2 days. Yield $=52 \%$. HRMS (ESI) $m / z$ calcd for $\mathrm{C}_{25} \mathrm{H}_{33} \mathrm{~N}_{8} \mathrm{O}(\mathrm{M}+\mathrm{H})$ 461.2777, found 461.2777; 
${ }^{1} \mathrm{H}$ NMR $\left(500 \mathrm{MHz},\left(\mathrm{CD}_{3}\right)_{2} \mathrm{SO}\right) \delta 9.15(\mathrm{~s}, 1 \mathrm{H}), 8.57$ (s, $\left.1 \mathrm{H}\right), 8.43$ $(\mathrm{d}, J=8.3 \mathrm{~Hz}, 1 \mathrm{H}), 7.41(\mathrm{~d}, J=1.9 \mathrm{~Hz}, 1 \mathrm{H}), 7.31(\mathrm{dd}, J=8.2,1.9 \mathrm{~Hz}$, $1 \mathrm{H}), 6.72(\mathrm{~d}, J=1.0 \mathrm{~Hz}, 1 \mathrm{H}), 6.43(\mathrm{~d}, J=9.5 \mathrm{~Hz}, 1 \mathrm{H}), 4.23(\mathrm{q}, J=$ $6.9 \mathrm{~Hz}, 2 \mathrm{H}), 4.13(\mathrm{dq}, J=9.4,6.6 \mathrm{~Hz}, 1 \mathrm{H}), 3.78(\mathrm{~s}, 3 \mathrm{H}), 2.38(\mathrm{~s}$, $3 \mathrm{H}), 1.41(\mathrm{t}, J=6.9 \mathrm{~Hz}, 3 \mathrm{H}), 1.16(\mathrm{~d}, J=6.6 \mathrm{~Hz}, 3 \mathrm{H}), 1.00(\mathrm{~s}, 9 \mathrm{H})$. $\mathrm{N}$-(2-Ethoxy-4-(4-methyl-4H-1,2,4-triazol-3-yl)phenyl)-6-methyl8-(pyrrolidin-1-yl)pyrido[3,4-d]pyrimidin-2-amine 46. Using 8chloro- $N$-(2-ethoxy-4-(4-methyl-4H-1,2,4-triazol-3-yl)phenyl)-6methylpyrido $[3,4-d]$ pyrimidin-2-amine 44 and pyrrolidine at $130{ }^{\circ} \mathrm{C}$. Yield $=70 \%$. HRMS (ESI) $m / z$ calcd for $\mathrm{C}_{23} \mathrm{H}_{27} \mathrm{~N}_{8} \mathrm{O}(\mathrm{M}+\mathrm{H})$ 431.2308, found 431.2315; ${ }^{1} \mathrm{H}$ NMR (500 MHz, $\left.\left(\mathrm{CD}_{3}\right)_{2} \mathrm{SO}\right) \delta 9.13$ $(\mathrm{s}, 1 \mathrm{H}), 8.56(\mathrm{~s}, 1 \mathrm{H}), 8.34(\mathrm{~s}, 1 \mathrm{H}), 8.23(\mathrm{~d}, J=8.2 \mathrm{~Hz}, 1 \mathrm{H}), 7.39-$ $7.29(\mathrm{~m}, 2 \mathrm{H}), 6.76(\mathrm{~d}, J=0.8 \mathrm{~Hz}, 1 \mathrm{H}), 4.21(\mathrm{q}, J=6.9 \mathrm{~Hz}, 2 \mathrm{H}), 3.88$ $(\mathrm{s}, 4 \mathrm{H}), 3.78(\mathrm{~s}, 3 \mathrm{H}), 2.37(\mathrm{~s}, 3 \mathrm{H}), 1.94-1.83(\mathrm{~m}, 4 \mathrm{H}), 1.41(\mathrm{t}, J=$ $6.9 \mathrm{~Hz}, 3 \mathrm{H})$.

8-(3,3-Dimethylazetidin-1-yl)-N-(2-ethoxy-4-(4-methyl-4H-1,2,4triazol-3-yl)phenyl)-6-methylpyrido[3,4-d]pyrimidin-2-amine 47. Using 8-chloro- $N$-(2-ethoxy-4-(4-methyl-4H-1,2,4-triazol-3-yl)phenyl)-6-methylpyrido[3,4- $d]$ pyrimidin-2-amine 44 and 3,3-dimethylazetidine hydrochloride. Yield $=70 \%$. HRMS (ESI) $\mathrm{m} / z$ calcd for $\mathrm{C}_{24} \mathrm{H}_{30} \mathrm{~N}_{8} \mathrm{O}(\mathrm{M}+2 \mathrm{H}) / 2$ 223.1266, found 223.1261; ${ }^{1} \mathrm{H}$ NMR (500 $\left.\mathrm{MHz}, \mathrm{CD}_{3} \mathrm{OD}\right) \delta 9.05(\mathrm{~s}, 1 \mathrm{H}), 8.56(\mathrm{~d}, J=8.5 \mathrm{~Hz}, 1 \mathrm{H}), 8.54(\mathrm{~s}, 1 \mathrm{H})$, $7.37(\mathrm{~d}, J=1.5 \mathrm{~Hz}, 1 \mathrm{H}), 7.34(\mathrm{dd}, J=8.5,1.5 \mathrm{~Hz}, 1 \mathrm{H}), 6.77(\mathrm{~s}, 1 \mathrm{H})$, $4.29(\mathrm{q}, J=7.0 \mathrm{~Hz}, 2 \mathrm{H}), 4.21(\mathrm{br} \mathrm{s}, 4 \mathrm{H}), 3.87(\mathrm{~s}, 3 \mathrm{H}), 2.44(\mathrm{~s}, 3 \mathrm{H})$, $1.54(\mathrm{t}, J=7.0 \mathrm{~Hz}, 3 \mathrm{H}), 1.38(\mathrm{~s}, 6 \mathrm{H})$.

8-(2,2-Dimethylazetidin-1-yl)-N-(2-ethoxy-4-(4-methyl-4H-1,2,4triazol-3-yl)phenyl)-6-methylpyrido[3,4-d]pyrimidin-2-amine 48. Using 8-chloro- $N$-(2-ethoxy-4-(4-methyl-4H-1,2,4-triazol-3-yl)phenyl)-6-methylpyrido[3,4-d]pyrimidin-2-amine 44 and 2,2-dimethylazetidine. Yield $=89 \%$. HRMS (ESI) $m / z$ calcd for $\mathrm{C}_{24} \mathrm{H}_{29} \mathrm{~N}_{8} \mathrm{O}$ $(\mathrm{M}+\mathrm{H}) 445.2459$, found $445.2461 ;{ }^{1} \mathrm{H} \mathrm{NMR}\left(500 \mathrm{MHz}, \mathrm{CD}_{3} \mathrm{OD}\right) \delta$ $8.98(\mathrm{~s}, 1 \mathrm{H}), 8.54(\mathrm{~s}, 1 \mathrm{H}), 8.52(\mathrm{~d}, J=8.0 \mathrm{~Hz}, 1 \mathrm{H}), 7.35(\mathrm{~d}, J=2.0$ $\mathrm{Hz}, 1 \mathrm{H}), 7.33(\mathrm{dd}, J=8.0,2.0 \mathrm{~Hz}, 1 \mathrm{H}), 6.65(\mathrm{~s}, 1 \mathrm{H}), 4.70-4.66(\mathrm{~m}$, $2 \mathrm{H}), 4.27(\mathrm{~d}, J=7.0 \mathrm{~Hz}, 2 \mathrm{H}), 3.85(\mathrm{~s}, 3 \mathrm{H}), 2.39(\mathrm{~s}, 3 \mathrm{H}), 2.22(\mathrm{dd}, J=$ 9.0, $7.5 \mathrm{~Hz}, 2 \mathrm{H}), 1.71(\mathrm{~s}, 6 \mathrm{H}), 1.54(\mathrm{t}, J=7.0 \mathrm{~Hz}, 3 \mathrm{H})$.

Biochemical Assays. MPS1 and CDK2 counterscreen assay were performed as reported previously. ${ }^{16}$

MSD Assay. An electrochemiluminescence assay (Meso Scale Discovery, MSD) for detection of autophosphorylation of MPS1 at $\mathrm{pTpS}^{33 / 37}$ sites in cell lysates has been described previously. ${ }^{16}$ Autophosphorylation of MPS1 at $\mathrm{pTpS}^{33 / 37}$ and total MPS1-GFP levels in MPS1-doxycycline inducible DLD-1 xenografts were determined by MSD assays as described previously. ${ }^{32}$ Results were presented as the ratio of Phospho-MPS1/Total MPS1.

Microsomal Metabolism. Microsomal clearance was determined in female CD1 mice, female Sprague-Dawley rats, and mixed gender human liver microsomes obtained from Tebu-Bio (Peterborough, U.K.) following incubation of $1 \mu \mathrm{M}$ compound at $37^{\circ} \mathrm{C}$ in $1 \mathrm{mg} / \mathrm{mL}$ microsomal protein, $3 \mathrm{mmol} / \mathrm{L} \mathrm{MgCl}_{2}, 1 \mathrm{mmol} / \mathrm{L} \mathrm{NADPH}, 2.5$ $\mathrm{mmol} / \mathrm{L}$, UDP-glucuronic acid, and $10 \mathrm{mmol} / \mathrm{L}$ phosphate buffer ( $\mathrm{pH}$ 7.4) (all purchased from Sigma-Aldrich, Gillingham, U.K). Reactions were started by addition of the cofactors following $10 \mathrm{~min}$ preincubation of microsomes with test compound and were terminated at $-1,0,5,10,15$, and $30 \mathrm{~min}$ with three volumes of ice-cold methanol containing internal standard. Samples were centrifuged at $2800 \mathrm{~g}$ for $30 \mathrm{~min}$ at $4{ }^{\circ} \mathrm{C}$ and the supernatants analyzed. Control incubations were prepared as above with omission of cofactors. Compound measurements were performed by LCMS on an Agilent quadrupole time-of-flight instrument (Agilent 6510) following separation with a 6 min gradient of $0.1 \%$ formic acid in methanol on a $50 \times 2.1 \mathrm{~mm} 2.6 \mu \mathrm{m} \mathrm{C18}$ column (Kinetex Phenomenex). For metabolite identification, the gradient was extended to $20 \mathrm{~min}$ and MS/MS carried out with fragment elucidation for ions of interest.

Pharmacokinetic Studies. Animals were adapted to laboratory conditions for at least 1 week prior to dosing and were allowed food and water ad libitum. Compounds were administered iv or po (mouse, $0.1 \mathrm{~mL} / 10 \mathrm{~g}$ in $10 \% \mathrm{DMSO}, 5 \%$ tween 20 in saline; rat, $0.05 \mathrm{~mL} / 10 \mathrm{~g}$ in $10 \%$ DMSO, $5 \%$ tween 20 in saline; dog, $10 \%$ in DMSO in saline). Blood samples were collected from the tail vein $(20 \mu \mathrm{L})$ at 8 time points over the $24 \mathrm{~h}$ post dose and spotted on Whatman B cards (VWR) together with a standard curve and quality controls spiked in control blood. Cards were allowed to dry at r.t. for at least 6 h. Cards were punched and $6 \mathrm{~mm}$ discs were extracted with $200 \mu \mathrm{L}$ of methanol containing $500 \mathrm{nM}$ olomoucine as an internal standard. Following centrifugation, extracts were analyzed by multiple reaction monitoring of precursor and product ions by ESI-LCMS/MS on a QTRAP 4000 (ABSciex) following gradient separation with $0.1 \%$ formic acid in methanol on a Phenomenex Kinetex C18 UPLC column $(50 \times 2.1 \mathrm{~mm}, 2.6 \mu \mathrm{M})$. Quantitation was carried out with an external calibration (typically 8 points ranging from $1 \mathrm{nM}$ to $25 \mu \mathrm{M}$ ). Quality controls were included (three concentrations) at the beginning and the end of the analytical run and were within $20 \%$ of nominal concentrations.

Pharmacokinetic parameters were derived from noncompartmental analysis using Phoenix Pharsight WinNonlin (model 200 and 201) version 6.1/6.3.

All experiments using animals were performed in accordance with the local Animal Welfare and Ethical Review Board, the UK Home Office Animals Scientific Procedures Act 1986, and with the United Kingdom National Cancer Research Institute Guidelines for the Welfare of Animals in Cancer Research. ${ }^{31}$ The ICR does not undertake research in nonrodent species and requires internal ethical review when such studies are sponsored by organizations with whom we collaborate. Collaborator-sponsored nonrodent pharmacology studies of compound 36 necessary for the prediction of therapeutic window and application to the clinic were approved by the ICR Animal Welfare and Ethics Review Board and were conducted in full compliance with national regulations at AAALAC accredited R\&D sites.

PK/PD Experiments. These experiments were conducted as previously described. ${ }^{32}$

\section{ASSOCIATED CONTENT}

\section{Supporting Information}

The Supporting Information is available free of charge on the ACS Publications website at DOI: 10.1021/acs.jmedchem.8b00690.

\section{Molecular formula strings (CSV)}

Experimental procedures and analytical data for all formamides (10-13 and 29-33) and corresponding intermediates, CYP, hERG activity, and P-gp efflux data as well as kinase selectivity profiling of 36 . Tables with standard deviations for all compounds as well as antiproliferative $\left(\mathrm{GI}_{50}\right)$ data for several compounds (PDF)

\section{Accession Codes}

The PDB ID code for 36 bound to MPS1 is $6 \mathrm{H} 3 \mathrm{~K}$.

\section{AUTHOR INFORMATION}

\section{Corresponding Author}

*Tel: +44 (0)20 8722 4353. E-mail: swen.hoelder@icr.ac.uk. ORCID

Julian Blagg: 0000-0002-7409-0323

Swen Hoelder: 0000-0001-8636-1488

\section{Present Address}

${ }^{\perp}$ (A.F.) SBA School of Science and Engineering, Lahore University of Management Sciences, D.H.A., Lahore 54792, Pakistan.

\section{Notes}

The authors declare the following competing financial interest(s): The authors are current or former employees of The Institute of Cancer Research, which has a commercial interest in the development of kinase inhibitors. 


\section{ACKNOWLEDGMENTS}

This work was supported by Cancer Research UK [grant number C309/A11566]. We also acknowledge the Cancer Research Technology Pioneer Fund and Sixth Element Capital for funding (to P.I.) and NHS funding to the NIHR Biomedical Research Centre. S.L. is also supported by Breakthrough Breast Cancer. We thank Dr. Amin Mirza, Dr. Maggie Liu, and Mr. Meirion Richards for their help with LC, NMR, and mass spectrometry. We are grateful to the staff of DIAMOND Light Source for their support during data collection.

\section{ABBREVIATIONS USED}

CDK2, cyclin-dependent kinase 2; Cl, clearance; hERG, human Ether-à-go-go-Related Gene; HLM, human liver microsomes; L.E., ligand efficiency; MLM, mouse liver microsomes; MPS, monopolar spindle kinase; MSD, MesoScale Discovery; MTT, 3-(4,5-dimethylthiazol-2-yl)-2,5-diphenyltetrazolium bromide; PARP, poly ADP ribose polymerase; PLK1, polo-like kinase; PTEN, phosphatase and tensin homologue; SAC, spindle assembly checkpoint; RLM, rat liver microsomes; $V_{s s}$, volume of distribution

\section{REFERENCES}

(1) Hardwick, K. G. The spindle checkpoint. Trends Genet. 1998, 14, $1-4$.

(2) Mills, G. B.; Schmandt, R.; McGill, M.; Amendola, A.; Hill, M.; Jacobs, K.; May, C.; Rodricks, A. M.; Campbell, S.; Hogg, D. Expression of TTK, a novel human protein kinase, is associated with cell proliferation. J. Biol. Chem. 1992, 267, 16000-16006.

(3) Lauze, E.; Stoelcker, B.; Luca, F. C.; Weiss, E.; Schutz, A. R.; Winey, M. Yeast spindle pole body duplication gene MPS1 encodes an essential dual specificity protein kinase. EMBO J. 1995, 14, 16551663.

(4) Musacchio, A.; Salmon, E. D. The spindle-assembly checkpoint in space and time. Nat. Rev. Mol. Cell Biol. 2007, 8, 379-393.

(5) Daniel, J.; Coulter, J.; Woo, J.-H.; Wilsbach, K.; Gabrielson, E. High levels of the MPS1 checkpoint protein are protective of aneuploidy in breast cancer cells. Proc. Natl. Acad. Sci. U. S. A. 2011, 108, 5384-5389.

(6) Brough, R.; Frankum, J. R.; Sims, D.; Mackay, A.; MendesPereira, A. M.; Bajrami, I.; Costa-Cabral, S.; Rafiq, R.; Ahmad, A. S.; Cerone, M. A.; Natrajan, R.; Sharpe, R.; Shiu, K.-K.; Wetterskog, D.; Dedes, K. J.; Lambros, M. B.; Rawjee, T.; Linardopoulos, S.; ReisFilho, J. S.; Turner, N. C.; Lord, C. J.; Ashworth, A. Functional viability profiles of breast cancer. Cancer Discovery 2011, 1, 260-273.

(7) Gordon, D. J.; Resio, B.; Pellman, D. Causes and consequences of aneuploidy in cancer. Nat. Rev. Genet. 2012, 13, 189-203.

(8) Lengauer, C.; Kinzler, K. W.; Vogelstein, B. Genetic instabilities in human cancers. Nature 1998, 396, 643-649.

(9) Carter, S. L.; Eklund, A. C.; Kohane, I. S.; Harris, L. N.; Szallasi, Z. A signature of chromosomal instability inferred from gene expression profiles predicts clinical outcome in multiple human cancers. Nat. Genet. 2006, 38, 1043-1048.

(10) Yuan, B.; Xu, Y.; Woo, J.-H.; Wang, Y.; Bae, Y. K.; Yoon, D.-S.; Wersto, R. P.; Tully, E.; Wilsbach, K.; Gabrielson, E. Increased expression of mitotic checkpoint genes in breast cancer cells with chromosomal instability. Clin. Cancer Res. 2006, 12, 405-410.

(11) Mizukami, Y.; Kono, K.; Daigo, Y.; Takano, A.; Tsunoda, T.; Kawaguchi, Y.; Nakamura, Y.; Fujii, H. Detection of novel cancertestis antigen-specific T-cell responses in TIL, regional lymph nodes, and PBL in patients with esophageal squamous cell carcinoma. Cancer Sci. 2008, 99, 1448-1454.

(12) Salvatore, G.; Nappi, T. C.; Salerno, P.; Jiang, Y.; Garbi, C.; Ugolini, C.; Miccoli, P.; Basolo, F.; Castellone, M. D.; Cirafici, A. M.; Melillo, R. M.; Fusco, A.; Bittner, M. L.; Santoro, M. A cell proliferation and chromosomal instability signature in anaplastic thyroid carcinoma. Cancer Res. 2007, 67, 10148-10158.

(13) Thykjaer, T.; Workman, C.; Kruhøffer, M.; Demtröder, K.; Wolf, H.; Andersen, L. D.; Frederiksen, C. M.; Knudsen, S.; Ørntoft, T. F. Identification of gene expression patterns in superficial and invasive human bladder cancer. Cancer Res. 2001, 61, 2492-2499.

(14) Wengner, A. M.; Siemeister, G.; Koppitz, M.; Schulze, V.; Kosemund, D.; Klar, U.; Stoeckigt, D.; Neuhaus, R.; Lienau, P.; Bader, B.; Prechtl, S.; Raschke, M.; Frisk, A.-L.; von Ahsen, O.; Michels, M.; Kreft, B.; von Nussbaum, F.; Brands, M.; Mumberg, D.; Ziegelbauer, K. Novel MPS1 kinase inhibitors with potent antitumor activity. Mol. Cancer Ther. 2016, 15, 583-592.

(15) Mason, J. M.; Wei, X.; Fletcher, G. C.; Kiarash, R.; Brokx, R.; Hodgson, R.; Beletskaya, I.; Bray, M. R.; Mak, T. W. Functional characterization of CFI-402257, a potent and selective MPS1/TTK kinase inhibitor, for the treatment of cancer. Proc. Natl. Acad. Sci. U. S. A. 2017, 114, 3127-3132.

(16) Naud, S.; Westwood, I. M.; Faisal, A.; Sheldrake, P.; Bavetsias, V.; Atrash, B.; Cheung, K.-M. J.; Liu, M.; Hayes, A.; Schmitt, J.; Wood, A.; Choi, V.; Boxall, K.; Mak, G.; Gurden, M.; Valenti, M.; de Haven Brandon, A.; Henley, A.; Baker, R.; McAndrew, C.; Matijssen, B.; Burke, R.; Hoelder, S.; Eccles, S. A.; Raynaud, F. I.; Linardopoulos, S.; van Montfort, R. L. M.; Blagg, J. Structure-based design of orally bioavailable $1 H$-pyrrolo[3,2-c] pyridine inhibitors of mitotic kinase monopolar spindle 1 (MPS1). J. Med. Chem. 2013, 56, 10045-10065.

(17) Innocenti, P.; Woodward, H. L.; Solanki, S.; Naud, S.; Westwood, I. M.; Cronin, N.; Hayes, A.; Roberts, J.; Henley, A. T.; Baker, R.; Faisal, A.; Mak, G. W.-Y.; Box, G.; Valenti, M.; De Haven Brandon, A.; O’Fee, L.; Saville, H.; Schmitt, J.; Matijssen, B.; Burke, R.; van Montfort, R. L. M.; Raynaud, F. I.; Eccles, S. A.; Linardopoulos, S.; Blagg, J.; Hoelder, S. Rapid discovery of pyrido[3,4-d]pyrimidine inhibitors of monopolar spindle kinase 1 (MPS1) using a structure-based hybridization approach. J. Med. Chem. 2016, 59, 3671-3688.

(18) Tardif, K. D.; Rogers, A.; Cassiano, J.; Roth, B. L.; Cimbora, D. M.; McKinnon, R.; Peterson, A.; Douce, T. B.; Robinson, R.; Dorweiler, I.; Davis, T.; Hess, M. A.; Ostanin, K.; Papac, D. I.; Baichwal, V.; McAlexander, I.; Willardsen, J. A.; Saunders, M.; Christophe, H.; Kumar, D. V.; Wettstein, D. A.; Carlson, R. O.; Williams, B. L. Characterization of the cellular and antitumor effects of MPI-0479605, a small-molecule inhibitor of the mitotic kinase MPS1. Mol. Cancer Ther. 2011, 10, 2267-2275.

(19) Tannous, B. A.; Kerami, M.; Van der Stoop, P. M.; Kwiatkowski, N.; Wang, J.; Zhou, W.; Kessler, A. F.; Lewandrowski, G.; Hiddingh, L.; Sol, N.; Lagerweij, T.; Wedekind, L.; Niers, J. M.; Barazas, M.; Nilsson, R. J. A.; Geerts, D.; De Witt Hamer, P. C.; Hagemann, C.; Vandertop, W. P.; Van Tellingen, O.; Noske, D. P.; Gray, N. S.; Würdinger, T. Effects of the selective MPS1 inhibitor MPS1-IN-3 on glioblastoma sensitivity to antimitotic drugs. J. Natl. Canc. Inst. 2013, 105, 1322-1331.

(20) Kusakabe, K.-I.; Ide, N.; Daigo, Y.; Itoh, T.; Yamamoto, T.; Kojima, E.; Mitsuoka, Y.; Tadano, G.; Tagashira, S.; Higashino, K.; Okano, Y.; Sato, Y.; Inoue, M.; Iguchi, M.; Kanazawa, T.; Ishioka, Y.; Dohi, K.; Kido, Y.; Sakamoto, S.; Ando, S.; Maeda, M.; Higaki, M.; Yoshizawa, H.; Murai, H.; Nakamura, Y. A unique hinge binder of extremely selective aminopyridine-based MPS1 (TTK) kinase inhibitors with cellular activity. Bioorg. Med. Chem. 2015, 23, 22472260.

(21) Laufer, R.; Ng, G.; Liu, Y.; Patel, N. K. B.; Edwards, L. G.; Lang, Y.; Li, S.-W.; Feher, M.; Awrey, D. E.; Leung, G.; Beletskaya, I.; Plotnikova, O.; Mason, J. M.; Hodgson, R.; Wei, X.; Mao, G.; Luo, X.; Huang, P.; Green, E.; Kiarash, R.; Lin, D. C.-C.; Harris-Brandts, M.; Ban, F.; Nadeem, V.; Mak, T. W.; Pan, G. J.; Qiu, W.; Chirgadze, N. Y.; Pauls, H. W. Discovery of inhibitors of the mitotic kinase TTK based on $N$-(3-(3-sulfamoylphenyl)-1H-indazol-5-yl)-acetamides and carboxamides. Bioorg. Med. Chem. 2014, 22, 4968-4997.

(22) Martinez, R.; Blasina, A.; Hallin, J. F.; Hu, W.; Rymer, I.; Fan, J.; Hoffman, R. L.; Murphy, S.; Marx, M.; Yanochko, G.; Trajkovic, D.; Dinh, D.; Timofeevski, S.; Zhu, Z.; Sun, P.; Lappin, P. B.; Murray, 
B. W. Mitotic checkpoint kinase MPS1 has a role in normal physiology which impacts clinical utility. PLoS One 2015, 10, e0138616.

(23) Maia, A. R. R.; de Man, J.; Boon, U.; Janssen, A.; Song, J. Y.; Omerzu, M.; Sterrenburg, J. G.; Prinsen, M. B. W.; WillemsenSeegers, N.; de Roos, J. A. D. M.; van Doornmalen, A. M.; Uitdehaag, J. C. M.; Kops, G. J. P. L.; Jonkers, J.; Buijsman, R. C.; Zaman, G. J. R.; Medema, R. H. Inhibition of the spindle assembly checkpoint kinase TTK enhances the efficacy of docetaxel in a triple-negative breast cancer model. Ann. Oncol. 2015, 26, 2180-2192.

(24) Wengner, A. M.; Siemeister, G. Combinations for the Treatment of Cancer Comprising a MPS-1 Kinase Inhibitor and a Mitotic Inhibitor. WO2014198645, 2014.

(25) Wengner, A. M.; Siemeister, G. Combination of a Imidazopyridazine Derivative and a Mitotic Agent for the Treatment of Cancer. WO2014198776A1, 2014.

(26) Kusakabe, K.-I.; Ide, N.; Daigo, Y.; Itoh, T.; Yamamoto, T.; Hashizume, H.; Nozu, K.; Yoshida, H.; Tadano, G.; Tagashira, S.; Higashino, K.; Okano, Y.; Sato, Y.; Inoue, M.; Iguchi, M.; Kanazawa, T.; Ishioka, Y.; Dohi, K.; Kido, Y.; Sakamoto, S.; Ando, S.; Maeda, M.; Higaki, M.; Baba, Y.; Nakamura, Y. Discovery of imidazo[1,2b]pyridazine derivatives: selective and orally available MPS1 (TTK) kinase inhibitors exhibiting remarkable antiproliferative activity. $J$. Med. Chem. 2015, 58, 1760-1775.

(27) Wahba, H. A.; El-Hadaad, H. A. Current approaches in treatment of triple-negative breast cancer. Cancer Biol. Med. 2015, 12, $106-116$.

(28) Innocenti, P.; Woodward, H.; O’Fee, L.; Hoelder, S. Expanding the scope of fused pyrimidines as kinase inhibitor scaffolds: synthesis and modification of pyrido[3,4-d]pyrimidines. Org. Biomol. Chem. 2015, 13, 893-904.

(29) VanderWel, S. N.; Harvey, P. J.; McNamara, D. J.; Repine, J. T.; Keller, P. R.; Quin, J.; Booth, R. J.; Elliott, W. L.; Dobrusin, E. M.; Fry, D. W.; Toogood, P. L. Pyrido[2,3-d]pyrimidin-7-ones as specific inhibitors of cyclin-dependent kinase 4. J. Med. Chem. 2005, 48, 2371-2387.

(30) Toogood, P. L.; Harvey, P. J.; Repine, J. T.; Sheehan, D. J.; VanderWel, S. N.; Zhou, H.; Keller, P. R.; McNamara, D. J.; Sherry, D.; Zhu, T.; Brodfuehrer, J.; Choi, C.; Barvian, M. R.; Fry, D. W. Discovery of a potent and selective inhibitor of cyclin-dependent kinase 4/6. J. Med. Chem. 2005, 48, 2388-2406.

(31) Workman, P.; Aboagye, E. O.; Balkwill, F.; Balmain, A.; Bruder, G.; Chaplin, D. J.; Double, J. A.; Everitt, J.; Farningham, D. A. H.; Glennie, M. J.; Kelland, L. R.; Robinson, V.; Stratford, I. J.; Tozer, G. M.; Watson, S.; Wedge, S. R.; Eccles, S. A. Guidelines for the welfare and use of animals in cancer research. Br. J. Cancer 2010, 102, 15551577.

(32) Faisal, A.; Mak, G. W. Y.; Gurden, M. D.; Xavier, C. P. R.; Anderhub, S. J.; Innocenti, P.; Westwood, I. M.; Naud, S.; Hayes, A.; Box, G.; Valenti, M. R.; De Haven Brandon, A. K.; O’Fee, L.; Schmitt, J.; Woodward, H. L.; Burke, R.; vanMontfort, R. L. M.; Blagg, J.; Raynaud, F. I.; Eccles, S. A.; Hoelder, S.; Linardopoulos, S. Characterisation of CCT271850, a selective, oral and potent MPS1 inhibitor, used to directly measure in vivo MPS1 inhibition vs therapeutic efficacy. Br. J. Cancer 2017, 116, 1166-1176.

(33) Milletti, F.; Storchi, L.; Sforna, G.; Cruciani, G. New and original pka prediction method using grid molecular interaction fields. J. Chem. Inf. Model. 2007, 47, 2172-2181. 